\title{
Money and Modern Banking without Bank Runs
}

\author{
David R. Skeie* \\ Federal Reserve Bank of New York
}

October 2006

\begin{abstract}
Bank runs in the literature take the form of withdrawals of demand deposits payable in real goods, which deplete a fixed reserve of goods in the banking system. That framework describes traditional bank runs based on currency withdrawals as occurred historically in the U.S. and more recently in developing countries. However, in a modern banking system, large withdrawals typically take the form of electronic payments within a clearinghouse system of banks. These transfers shift balances among banks, with no analog of a depletion of a scarce reserve from the banking system. A new framework of nominal demand deposits repayable in money within a clearinghouse can examine bank run threats in a modern developed economy. This approach shows that interbank lending and monetary prices may be able to prevent pure liquidity-driven bank runs, demonstrating the resiliency of modern banking systems to excessive withdrawals. This finding suggests that the rationalization for deposit insurance based on the Diamond-Dybvig model of real demand deposits holds for developing countries but not necessarily for developed countries.
\end{abstract}

JEL Classification: G21, G28, E42

Keywords: Bank runs, nominal contracts, demand deposits, interbank market, clearinghouse, payments, deposit insurance

\footnotetext{
*Email: david.skeie@ny.frb.org. This paper is a revised portion of a previously circulated paper, "Money and Modern Bank Runs," which is the first chapter of my dissertation thesis at Princeton. I am grateful to my advisors Franklin Allen, Ben Bernanke and Patrick Bolton, and to Ken Ayotte, Markus Brunnermeier, Ed Green, Yair Listokin, Guido Lorenzoni, Antoine Martin, Jamie McAndrews, Cyril Monnet, Wei Xiong, seminar participants at Federal Reserve Bank of Chicago, Federal Reserve Bank of New York, Federal Reserve Bank of Richmond, Federal Reserve Board of Governors, FDIC, NYU Stern, Princeton, UNC Chapel Hill Kenan-Flager, Wharton, Sveriges Riksbank Workshop on "Banking, Financial Stability and the Business Cycle," 2004 SED Annual Meeting (Florence), 2005 FMA Annual Meeting (Chicago), JBF 30th Anniversary Conference (Beijing) and 2006 FIRS Conference (Shanghai) for helpful comments and conversations. The views expressed in this paper are those of the author and do not necessarily reflect the views of the Federal Reserve Bank of New York or the Federal Reserve System. All errors are mine.
} 


\section{Introduction}

The number of countries with deposit insurance has more than quadrupled to 87 since the classic paper by Diamond and Dybvig (1983) was published. ${ }^{1}$ Their paper serves as a major theoretical justification for deposit insurance by claiming that it prevents otherwise inevitable liquidity-based bank runs. However, some evidence suggests that deposit insurance may hurt more than help. Deposit insurance may reduce monitoring of banks and increase moral hazard and portfolio volatility, ${ }^{2}$ leading to a greater probability of bank failures, ${ }^{3}$ with the S\&L crisis in the 1980 s as a leading example. ${ }^{4}$ Several authors argue that deposit insurance is adopted by countries based on rent-seeking private interests due to political power. ${ }^{5}$ While developing countries have recently increasingly adopted deposit insurance, developed countries have been the primary adopters overall, and have been particularly linked to the private-interests theory. ${ }^{6}$

This paper studies how the threat of bank runs in developed countries differs from that in developing countries, which has implications for the Diamond-Dybvig justification for deposit insurance in each case. To reflect the modern economy and banking system of developed countries, as defined below, I introduce a new framework of nominal monetary demand deposits into a Diamond-Dybvig setting, in which banks pay withdrawals in monetary payments through a clearinghouse system of banks. In this framework, interbank lending and a monetary-priced market for goods may be able to prevent pure liquidity-driven bank runs that occur in Diamond-Dybvig.

A nominal deposits framework contrasts with the standard real deposits framework in current theory. Starting with Diamond-Dybvig, banks are modeled in the literature as paying withdrawals of deposits in real goods. The excessive early withdrawals of deposits are initially triggered due to various causes in the different strands of the literature, including multiple equilibria following Diamond-Dybvig and asymmetric information regarding asset shocks following Chari and Jagannathan (1988) and Calomiris and Kahn (1991). In all of these strands of the general real deposits framework, excessive withdrawals deplete a fixed reserve of liquid real goods available to be paid out from the banking system. Be-

\footnotetext{
${ }^{1}$ Demirguc-Kunt (2005).

${ }^{2}$ Kim and Santomero (1988), Martin (2006), Nagarajan and Sealey (1995) and Penati and Protopapadakis (1988).

${ }^{3}$ Demirguc-Kunt and Detragiache (1997, 2002).

${ }^{4}$ Kane (1989).

${ }^{5}$ Kroszner (1998), Kroszner and Strahan (2001) and Laeven (2004).

${ }^{6}$ Demirguc-Kunt et al. (2005).
} 
cause demand deposits are modeled as fixed promises of goods, payments to withdrawers cannot be rationed. Long term investments have to be inefficiently liquidated to provide short term payouts. The bank will not be able to pay future withdrawals, so all depositors try to withdraw immediately. This bank run is inevitable in the real deposits framework due to the fragile liquidity structure of the bank's real short term liabilities versus real long term assets, even though the bank may be otherwise fundamentally solvent. Deposit insurance provides guarantees to depositors on their withdrawals, so that they do not run the bank.

The real deposit models of bank runs describe traditional depositor runs that typically occur in developing countries and that occurred historically in the U.S. during the 19th and early 20th century. Gorton (1988) and Friedman and Schwartz (1963) show that during banking crises in this era of the U.S., the ratio of currency to deposits increased. This implies that depositors withdrew currency and stored it outside of the banking system, corresponding to bank run models in which real goods are withdrawn from the banking system. Allen and Gale (1998) and Smith (2003) cite the withdrawals of currency from the banking system during these historical bank runs as what their models explain. Diamond and Rajan (2005) state their real deposit model most closely resembles the gold standard era in the U.S., with an inflexible value of money, and the recent banking crisis in Argentina, with deposits repayable in dollars that could be withdrawn from the country.

The major threat from excessive withdrawals is different in a modern economy and banking system, defined as one with a floating currency, bank deposits denominated in domestic currency, and a modern clearinghouse payments system. Large bank withdrawals typically take the form of intraday electronic transfers of money between banks within a clearinghouse. ${ }^{7}$ While money balances shift among banks, there is no correspondence to the real-deposits bank run literature of a depletion of a scarce reserve. An example is a wholesale depositor who does not roll over large CDs at a bank and redeposits the funds elsewhere, or withdraws to make purchases. Regardless, the money from the wholesaler's account at his current bank is sent to either his new account at a different bank or to the

\footnotetext{
${ }^{7}$ An electronic withdrawal is much more practical and timely than a costly and risky physical withdrawal of a large sum of currency, especially if there is an imminent run on a bank. Demirguc-Kunt et al. (2004) show that in contemporary times, aggregate bank deposits do not significantly decline during times of financial distress, especially in developed countries and even in many less-developed economies. This strongly suggests that currency is not withdrawn from the banking system in any critical amount in modern economies. Skeie (2004) examines nominal deposits allowing for withdrawals of currency, which may be stored outside of the banking system, in addition to withdrawals in the form of banking payments within a clearinghouse considered here.
} 
bank of the party who is selling to the wholesaler. The receiving bank may then lend out or pay these funds yet again to other banks during the same day.

A new approach is needed to examine the threat of bank runs in a modern economy. I develop a model of nominal demand deposits that are withdrawn by depositors as electronic payments within a clearinghouse. This approach highlights how a modern banking system is resilient to excessive withdrawals in two ways. First, it shows that fundamentally, the interbank market always has available any amount of funds that are demanded for withdrawal and interbank loans. If all depositors withdraw from a bank, all funds are paid to a second bank for either redeposits or purchases. The second bank always has the capability of lending back to the first bank. Moreover, it prefers to lend back if the run is triggered for pure liquidity reasons, as in Diamond-Dybvig. Lending to prevent the liquidation of the first bank's current long term investments is naturally most efficient and pays the greatest return on funds. Thus, the first bank does not fail, even with excess early withdrawals, so pure liquidity-driven runs do not occur in equilibrium in the first place.

In contrast, the literature shows that by design, when demand deposits are repayable in goods, interbank lending cannot prevent large enough pure liquidity runs. ${ }^{8}$ If the aggregate amount of early withdrawals is greater than the total amount of liquid goods held by all banks, there are not enough liquid goods available to lend and runs occur. This paper points out that unless currency is withdrawn and stored outside of the banking system, bank reserves are not drained from the banking system in a closed economy absent central bank intervention. When deposits are repayable in monetary claims within a clearinghouse, an interbank market for money has the capacity to lend to a bank in need regardless of the amount of withdrawals, so interbank lending can in principle prevent liquidity runs.

Second, the approach in this paper shows that nominal deposits hedge banks individually or in aggregate against excessive early withdrawals. Banks initially lend money to entrepreneurs who store and invest goods and then sell them on the current goods market. If depositors run a bank by making excessive early withdrawals to purchase goods, an abundance of money to buy goods drives the price up in the early period. The bank's short term liabilities increase in nominal but not real value, since deposits are nominal and

\footnotetext{
${ }^{8}$ Bhattacharya and Gale (1987), Bhattacharya and Fulghieri (1994), Allen and Gale (2000a, 2004), Aghion et al. (2000) and Diamond and Rajan (2005).
} 
the price level increases. In real value terms, the bank's short term assets decrease but its long term assets increase, leaving it fundamentally solvent. The bank can borrow back from the interbank market the excess funds it paid out, requiring no liquidation of long term assets. Higher prices in the goods market ration consumption to early purchasers and save goods for those who do not run the bank. Depositors face lower relative prices at the later period and prefer to purchase goods then, so a run never occurs in equilibrium. Moreover, the price mechanism in the goods market provides the (ex-ante) optimal allocation of goods among consumers.

Several papers in the literature examine reduced form or partial equilibrium models of money for deposit withdrawals and interbank or central bank loans. ${ }^{9}$ However, these are models of real, not nominal, demand deposits. Money paid for deposit withdrawals is either consumed or withdrawn from the economy, with no market for goods and no endogenous monetary price level. ${ }^{10}$ I show that with a general equilibrium model of money, monetary prices imply nominal deposits hedge banks when there are excess withdrawals by depositors purchasing goods.

An implication from the nominal deposits framework is that Diamond-Dybvig does not necessarily justify deposit insurance for preventing pure liquidity-driven runs in developed countries. In contrast, the justification for deposit insurance based on Diamond-Dybvig is clarified for developing countries with non-modern economies and banking systems. Deposit insurance is needed in these countries where currency typically has a fixed value and is often withdrawn and held outside of the banking system.

This paper does not claim that bank runs cannot occur in a modern economy. Rather, the focus of this paper is to show the fundamental differences between nominal and real deposits frameworks by using a simple, frictionless interbank market to examine liquidity runs. While the model suggests that pure liquidity shocks do not provide for a complete rationalization for deposit insurance, other justifications for deposit insurance may be produced in this framework when additional frictions are added. For example, if an individual bank has large real asset losses, it will fail due to fundamental insolvency, which will trigger a run. Deposit insurance may be helpful for an orderly liquidation.

\footnotetext{
${ }^{9}$ Bryant (1980), Calomiris and Kahn (1991), Chang and Velasco (2000), Freixas et al. (2000, 2004), Freixas and Holthausen (2005), Gale and Vives (2002), Peck and Shell (2003), Postlewaite and Vives (1987), Repullo (2000) and Rochet and Vives (2004).

${ }^{10}$ Martin (2005) shows that central bank lending in a real deposits model describes historical commodity money rather than modern fiat money as in the nominal deposits model of Martin (2006), which follows Allen and Gale (1998).
} 
However, failures of banks are special relative to other firms because of their fragile liability structure of long term assets and short term liabilities. In order to distinguish the real effects of asset solvency shocks from the liquidity effects of liability shocks-i.e. excessive depositor withdrawals - the liquidity effect of nominal contracts and interbank monetary payments to lessen or compound runs must be understood. For example, Skeie (2004) shows that with nominal deposits, systematic real asset losses do not lead to bank runs; but a coordination failure in the interbank market causes not only bank runs but also contagion, which requires a lender of last resort rather than deposit insurance to resolve. These results with nominal contracts are due to a nominal monetary price mechanism, which is not present in real deposit models. Thus, it is important that real deposit models of bank runs that are triggered by asset shocks and asymmetric-information should also be re-examined in a nominal deposits and interbank payments framework.

This paper relates particularly to a few other works. Allen and Gale $(1998,2000 \mathrm{~b})$ add nominal contracts through central bank loans of currency, which the bank pays depositors in addition to goods, in order to deflate the real value of deposit withdrawals during an equilibrium bank run. The currency is stored outside of the banking system by withdrawers until a later period, when they use it to purchase goods from the bank. The bank repays the currency to the central bank and pays remaining depositors in real goods for their withdrawals. In the current study, nominal deposits are contracted ex-ante to repay only in money, so that during a potential run prices would rise and real deposit values would fall endogenously, which prevents bank runs in equilibrium. ${ }^{11}$

Diamond and Rajan (2006) and Champ et al. (1996) examine bank runs with nominal contracts and money in general equilibrium. ${ }^{12}$ They are explicit in modeling how bank runs result if there is a large enough demand for currency withdrawals out of the banking system. Diamond and Rajan (2006) also examine the bank's asset side and show that nominal contracts cannot prevent bank runs caused by idiosyncratic delays in asset returns. I examine the bank's liability side and show that nominal contracts can prevent bank runs caused by depositor liquidity-driven withdrawals.

Jacklin (1987) shows that depositors purchasing assets with real bank deposits destroy

\footnotetext{
${ }^{11}$ Skeie (2004) shows that with the model of nominal deposits in the current study, prices would respond to the aggregate asset shocks in Allen and Gale (1998) to achieve their optimal consumption allocation without the bank runs or central bank injections of currency that occur in Allen and Gale (1998). This also suggests that nominal contracts as modeled in the current study would prevent runs in the case of aggregate shocks in the fraction of consumers who fundamentally need to withdraw early.

${ }^{12}$ See also Boyd et at. (2004a, 2004b).
} 
the bank's optimal risk sharing. I show a very different point that depositors purchasing current goods with nominal bank deposits achieve the bank's optimal risk sharing. Jacklin (1987) also shows that an equity market can replicate the optimal risk sharing of a bank that issues real deposits, without bank runs. I show that a bank that issues nominal deposits can also replicate the optimal risk sharing of a bank that issues real deposits, without bank runs. This paper also relates to the literature on clearinghouse payment systems and interbank markets, by developing a model of a clearinghouse in which monetary payments are driven by and important for real economic activity. ${ }^{13}$

Section 2 presents and gives results for the underlying real model. Section 3 introduces the nominal deposit model. Section 4 shows how prices in the goods market can prevent runs with a single representative bank. Section 5 develops the clearinghouse model and shows how the interbank market can prevent runs with multiple banks. Section 6 extends the results from a centralized goods market to a sequential goods market, in which price dynamics reflect the discovery of a potential bank run over time. Section 7 discusses the results, and Section 8 concludes with potential implications regarding deposit insurance. The Appendix examines the robustness of price determinacy and includes the proofs that are not in the text.

\section{Real Goods Model}

\subsection{The Environment}

The environment of the real model, without money and entrepreneurs, is that which has become standard in the literature based on Diamond and Dybvig (1983). There are three periods, $t=\{0,1,2\}$. A continuum of ex-ante identical consumers with unit mass is endowed with a unit mass of a good at $t=0$. At $t=1$, a fraction $\lambda \in(0,1)$ of consumers receive an unverifiable liquidity shock and need to consume in that period. These "early" consumers have utility given by $U=u\left(c_{1}\right)$, where $c_{1}$ is their consumption in $t=1$. The remaining fraction $1-\lambda$ are "late" consumers. They have utility $U=u\left(c_{2}\right)$, where $c_{2}$ is their consumption in $t=2$. Late consumers can store any goods they receive in $t=1$ for consumption in $t=2$. Consumption $c_{t}$ is expressed as goods per unitsized consumer. The allocation consumed by early and late consumers is expressed as

\footnotetext{
${ }^{13}$ See for example Rochet and Tirole (1996), Flannery (1996), Freeman (1996), Green (1999a, 1999b), Henckel et al. (1999) and McAndrews and Roberds (1995, 1999).
} 
$\left(c_{1}, c_{2}\right)$. Period utility functions $u(\cdot)$ are assumed to be twice continuously differentiable, increasing, strictly concave and satisfy Inada conditions $u^{\prime}(0)=\infty$ and $u^{\prime}(\infty)=0$. I make the typical assumption following Diamond-Dybvig that the consumers' coefficient of relative risk aversion is greater than one, which implies that banks provide risk-decreasing insurance against liquidity shocks.

At $t=\{0,1\}$, any fraction of goods can be stored for a return of one in the following period. At $t=0$, any fraction of goods can alternatively be invested for a return of $r>1$ at $t=2$. These invested goods can be liquidated for a salvage return of $s<1$ at $t=1$ and zero return at $t=2$, which reflects the inefficiency of liquidation.

\subsection{Optimal Allocation}

The (ex-ante) optimal allocation for consumers is what a benevolent planner could provide based on observing consumer types to maximize a consumer's expected utility. This establishes a benchmark to compare against banking allocations. The planner's problem is:

$$
\begin{aligned}
\max _{c_{1}, c_{2}, \alpha, \gamma} & \lambda u\left(c_{1}\right)+(1-\lambda) u\left(c_{2}\right) \\
\text { s.t. } & \lambda c_{1} \leq 1-\alpha+\gamma s \\
& (1-\lambda) c_{2} \leq(\alpha-\gamma) r+1-\alpha+\gamma s-\lambda c_{1},
\end{aligned}
$$

where $\alpha \leq 1$ is the fraction of goods that are invested at $t=0$, and $\gamma \leq \alpha$ is the amount of goods invested at $t=0$ that are liquidated at $t=1$. The first constraint says that early consumers can only consume from goods stored at $t=0$ plus invested goods that are liquidated at $t=1$. The second constraint says that late consumers can only consume from returns of invested goods that are not liquidated and current goods available at $t=1$ that are not consumed by early consumers. Optimal consumption requires that early consumers only consume from goods stored at $t=0$, and that late consumers only consume from the returns of invested goods. This ensures no inefficient liquidation and no underinvestment of goods. The first-order conditions and binding constraints give the 
solution as the optimal allocation $\left(c_{1}^{*}, c_{2}^{*}\right)$ and optimal choice of $\alpha^{*}$ and $\gamma^{*}$, defined by

$$
\begin{aligned}
\frac{u^{\prime}\left(c_{1}^{*}\right)}{u^{\prime}\left(c_{2}^{*}\right)} & =r \\
\lambda c_{1}^{*} & =1-\alpha^{*} \\
(1-\lambda) c_{2}^{*} & =\alpha^{*} r \\
\gamma^{*} & =0 .
\end{aligned}
$$

Equation (1) shows that the ratio of marginal utilities between $t=1$ and $t=2$ is equal to the marginal rate of transformation $r$.

\subsection{Spot-Market Solution}

A spot market in which invested goods are traded for current goods by consumers at $t=1$ is not able to achieve the optimal allocation, a well-known result that generates the role for a bank. In a spot market, consumers invest $\alpha$ goods and store $1-\alpha$ goods at $t=0$. At $t=1, \lambda$ early consumers trade their $\alpha$ invested goods for the $1-\alpha$ stored goods of $1-\lambda$ late consumers at price $p_{i n v}$, expressed as current goods per invested good. In equilibrium, $p_{i n v}=\frac{(1-\lambda)(1-\alpha)}{\lambda \alpha}=1$. After trading in the market, consumption for early and late types is

$$
\begin{aligned}
c_{1} & =1-\alpha+\frac{\alpha}{p_{\text {inv }}}=1 \\
c_{2} & =\left[\alpha+(1-\alpha) p_{\text {inv }}\right] r=r .
\end{aligned}
$$

The assumption of the coefficient of relative risk aversion greater than one implies $c_{1}^{*}>1$ and $c_{2}^{*}<r,{ }^{14}$ so the market allocation does not provide enough goods to early consumers at $t=1$. Since $p_{\text {inv }}=1$ implies $1-\alpha=\lambda$, whereas $c_{1}^{*}>1$ implies from (2) that $1-\alpha^{*}>\lambda$, the amount of stored goods is less than optimal: $1-\alpha<1-\alpha^{*}$.

Optimal consumption for early consumers requires in effect an insurance payoff against their early consumption shock. However, standard insurance cannot be provided since types are not verifiable. Neither would consumers store enough goods at $t=0$ to provide this insurance through the spot market, which would require late consumers at $t=1$ to pay a higher price than $p_{i n v}=1$ for the invested goods sold by the early types at $t=1$.

\footnotetext{
${ }^{14}$ The coefficient of relative risk aversion $\frac{-c u^{\prime \prime}(c)}{u^{\prime}(c)}>1$ implies that $c u^{\prime}(c)$ is decreasing in $c$. Hence, $u^{\prime}(1)>r u^{\prime}(r)$, so from $(1), c_{1}^{*}>1, c_{2}^{*}<r$.
} 
Rather, if $p_{i n v}>1$ were expected, all consumers would invest even more goods at $t=0$ to sell at high $t=1$ prices, which would imply $p_{i n v}<1$. Thus, this is not an equilibrium.

I provide a novel result that shows the market does provide optimal consumption if consumers are forced to store the optimal amount of goods at $t=0$. This is important because it suggests that a key role of a bank is to ensure sufficient amounts of liquid goods, and with this provision markets can distribute goods efficiently. If consumers were forced to store $1-\alpha^{*}$ goods, the market achieves the optimal outcome. Early consumers would trade $\alpha^{*}$ invested goods for $1-\alpha^{*}$ stored goods from late consumers at $t=1$ at a market price of $p_{i n v}=\frac{c_{1}^{*}}{c_{2}^{*}} r>1$.

Proposition 1. The allocation in the unique market equilibrium when consumers are required to store $1-\alpha^{*}$ and invest $\alpha^{*}$ is the consumers' optimal outcome $\left(c_{1}^{*}, c_{2}^{*}\right)$.

Proof. See Appendix.

\subsection{Banking Solution with Real Goods Deposits}

A bank can offer demand deposits repayable in real goods to provide the optimal allocation for consumers as an equilibrium outcome, which is the seminal Diamond-Dybvig result. Consumers deposit their goods with the bank at $t=0$ for a real goods demand deposit contract. The deposit contract pays a return of either $c_{1}^{*}$ or $c_{2}^{*}$ in goods on demand to a depositor who withdraws at either $t=1$ or $t=2$, respectively. Withdrawals are payable according to a sequential service constraint, or first-come first-served until the bank's current and invested goods are depleted. The bank is owned by its depositors for the purpose of maximizing their $t=0$ expected utility. At $t=0$, the bank stores $1-\alpha^{*}$ goods and invests $\alpha^{*}$ goods. Since the first-order condition (1) implies $c_{2}^{*}>c_{1}^{*}$, the incentive constraint for consumers to truthfully reveal their type is satisfied in the "good" equilibrium. Early consumers withdraw at $t=1$ and late consumers withdraw at $t=2$.

A bank run is a possible equilibrium as well, however. If at $t=1$ late consumers believe that all other late consumers are going to withdraw early at $t=1$ from the bank, it is a best response for each to withdraw early and a bank run occurs. Real-goods demand deposit contracts require the bank to liquidate investments for excess withdrawals at $t=1$, causing a default on repayments by the bank and a sub-optimal allocation for consumers. Deposit insurance guarantees that late consumers are as well off by withdrawing at $t=2$ 
as at $t=1$, even if there is a run. Late consumers do not withdraw early, so deposit insurance implies a bank run is no longer an equilibrium.

\section{Money and Nominal Deposits Model}

I extend the real banking model such that demand deposits are repayable in money. To combine money and banking, I introduce a simple model of an "ideal banking system" as proposed by Wicksell. ${ }^{15}$ A bank holds nominal deposits and loans. All payments in the economy are made internal to a single bank in this section and made within a clearinghouse system of multiple banks in Section 5. For simplicity, no reserves are held by banks, which implies an infinite money multiplier on deposits. This corresponds to a system of free banking, or laissez-faire, with the assumptions of no currency payments and no frictions within the interbank payment and lending system. As Wicksell suggests, reserves are not fundamentally necessary if payments (his "medium of exchange") are made in a unit of account that is nominal, which corresponds to his "measure of value" of money divorced from metal (or goods).

I also extend the real banking model such that the real storage and investment of goods are done by entrepreneurs outside of the bank. A unit continuum of entrepreneurs take loans from the bank to purchase goods, which the entrepreneurs store and invest. They sell proceeds on a goods market at $t \in\{1,2\}$ to repay the loan. Entrepreneurs have no endowment, are risk neutral and maximize profits in terms of unsold goods they consume

\footnotetext{
15 "If customers are in direct business contact the money need never leave the bank at all, but payment can be made by a simple transfer from one banking account to another... If we suppose for the sake of simplicity that all such business is concentrated in a single bank... All payments will be made by cheques drawn on the payer's banking account, but these cheques will never lead to any withdrawals of money from the bank, but only to a transfer to the payee's account in the books of the bank... The lending operations of the bank will consist rather in its entering in its books a fictitious deposit equal to the amount of the loan, on which the borrower may draw... [P]ayments...must naturally lead to a credit with another person's (seller's) account, either in the form of a deposit paid in or of a repayment of a debt..."

"The ideal banking system sketched above has in recent times engaged the attention of many writers...and various proposals for its realization have been made. That developments tend in this direction is clear. We need only look at the English, German, and American banks with their 'clearing house'... Theoretically this imaginary system is of extraordinary interest... Some authors, both earlier and more recent have leaned to the view...that mere 'bank cover', i.e. the holding of bills and securities in the portfolios of the banks as the sole basis of note issues and cheques would be the ideal... Indeed, our modern monetary system is afflicted by an imperfection, an inherent contradiction. The development of credit aims at rendering the holding of cash reserves unnecessary, and yet these cash reserves are a necessary, though far from sufficient guarantee of the stability of money values... Only by completely divorcing the value of money from metal...and by making...the unit employed in the accounts of the credit institutions, both the medium of exchange and the measure of value - only in this way can the contradiction be overcome and the imperfection be remedied."

Knut Wicksell (1906), Lectures on Political Economy, Volume Two: Money
} 
at the end of $t=2$. Due to competition, I assume entrepreneurs are subject to a zero profit condition. Without loss of generality, I treat the continuum of entrepreneurs as a single competitive entrepreneur who is a price taker.

\subsection{Nominal Unit of Account}

At $t=0$, the bank issues loans and takes deposits denominated in a nominal unit of account, which is created using the following ad-hoc technique. A central bank exists only at $t=0$. It creates fiat currency with which it stands ready to buy and (to the extent feasible) sell goods at a fixed price of $P_{0}=1$. The central bank receives all currency back by the end of the $t=0$ period and plays no role thereafter. Even though the supply of central bank money is zero after $t=0$, the role of central bank currency as a nominal unit of account carries over to later periods due to monetary contracts established at $t=0 .{ }^{16}$

As illustrated in Figure 1, consumers sell their one unit of goods to the central bank for one unit of central bank currency at price $P_{0}=1$. The consumers deposit their currency $I_{0}=1$ in the bank in exchange for a nominal demand deposit contract. The deposit contract pays a return of either $D_{1}$ or $D_{2}{ }^{17}$ in monetary payments on demand when a depositor withdraws at either $t=1$ or $t=2$, respectively, subject to a sequential service constraint. The bank sets

$$
\begin{aligned}
& D_{1}=c_{1}^{*} \\
& D_{2}=c_{2}^{*} .
\end{aligned}
$$

The bank lends the unit of central bank currency to the entrepreneur for the nominal loan contract repayments of

$$
\begin{aligned}
& K_{1}=1-\alpha \\
& K_{2}=\alpha r
\end{aligned}
$$

due at $t=1$ and $t=2$, respectively, where $K_{t}$ is payable in monetary payments. The entrepreneur buys the good from the central bank with its currency. The bank sets $\alpha=\alpha^{*}$

\footnotetext{
${ }^{16}$ A similar process for money sequentially taking on an abstract unit of account, which is ultimately based on an original commodity value, is described by Kitson (1895), pages 6-8, and von Mises (1912/1971), pages 108-123.

${ }^{17}$ Uppercase letters denote variables with nominal values and lowercase letters continue to denote variables with real values.
} 


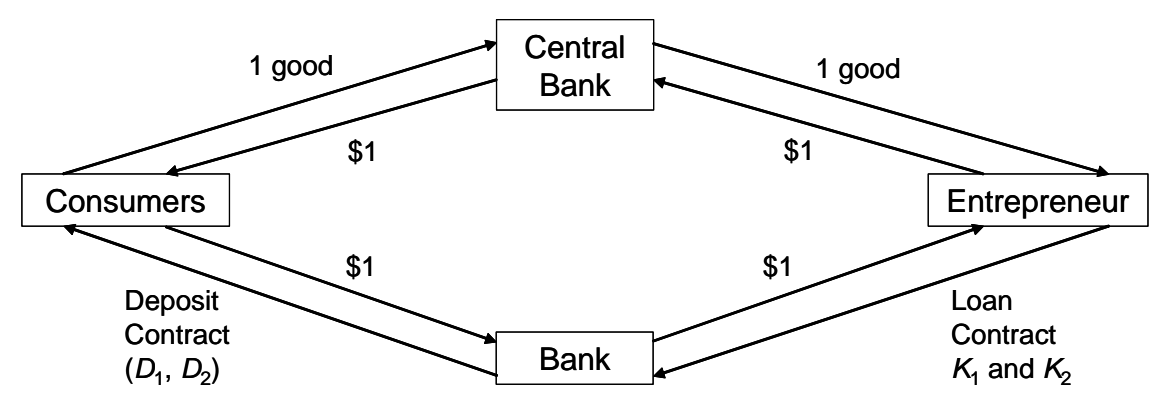

Figure 1: Introduction of Nominal Contracts at $t=0 . A$ central bank buys and sells goods with fiat currency at a fixed price of $P_{0}=1$ to establish nominal contracts. Consumers sell their good to the central bank for currency. They deposit the currency in the bank for a nominal demand deposit contract $\left(D_{1}, D_{2}\right)$, which repays $D_{t}$ upon withdrawal at either $t=1$ or $t=2$. The bank lends the currency to the entrepreneur for the nominal loan contract repayments of $K_{1}$ and $K_{2}$ due at $t=1$ and $t=2$, respectively. The entrepreneur buys the good from the central bank with the currency.

and can ensure that the entrepreneur stores $1-\alpha=1-\alpha^{*}$ and invests $\alpha=\alpha^{*}$ at $t=0$. This is a key function of a bank, since as suggested above, the market allocation of consumption is optimal once sufficient storage is enforced.

At the end of this exchange at $t=0$, the net holdings are as follows. The central bank holds all the currency and does not hold any goods. The consumer holds the demand deposit account that repays $D_{t}$. The entrepreneur holds $1-\alpha$ stored goods and $\alpha$ invested goods. The bank holds the loan contracts that repay $K_{1}$ and $K_{2}$ from the entrepreneur. ${ }^{18}$

\subsection{Timeline}

A bank run in Diamond-Dybvig can be interpreted as a fear either that the bank will default on withdrawals at $t=2$, or that long term investments will be liquidated and depleted, leaving no consumption goods available at $t=2$. These interpretations are indistinguishable, because bank deposits are repayable in consumption goods. These interpretations are made clear in this paper by the distinction of the withdrawal of deposits from the purchase of consumption goods. If late depositors fear their bank will default on withdrawal payments at $t=2$, they can withdraw money to redeposit at a different bank at $t=1$. I call this a "redeposit run," and examine it in Section 5 with a multiple-bank

\footnotetext{
${ }^{18}$ Money and nominal contracts could be introduced without the central bank actually exchanging goods for currency, but with just the guarantee to do so at $t=0$, which still establishes the nominal unit of account. Consumers could deposit goods directly with the bank for the nominal demand deposit account of $D_{t}$ and the bank would lend the goods to entrepreneurs for $K_{1}$ and $K_{2}$.
} 
model in which depositors can withdraw either to redeposit or to purchase goods. If late consumers fear that a bank run will lead to the liquidation of investments and the depletion of consumption goods from the goods market, they can withdraw money to purchase goods at $t=1$. I call this a "purchase run," and examine it first with a single-bank model in which depositors can withdraw only to purchase goods.

In the single-bank model, monetary payments are made by debiting and/or crediting accounts internal to the bank. Depositor withdrawals at $t=1$ or $t=2$ are made by debiting the depositor's account and crediting the entrepreneur's account at the bank. These withdrawals are recorded as a demand schedule with a Walrasian auctioneer, and the entrepreneur simultaneously submits a supply schedule $q_{t}^{S}$ to the auctioneer. The entrepreneur then repays $K_{t}$ if possible, which debits the entrepreneur's account and credits the bank's account. If the entrepreneur's account nets out to be negative, he defaults at period $t$ and must liquidate and sell all goods possible, defined as $\widehat{q}_{t}^{S}$, in attempt to repay his loan. If the entrepreneur has positive net credits in his account at $t=1$, the are held as deposits. I assume the bank pays a return on deposits made at $t=1$ of

$$
D_{1,2}=\frac{D_{2}}{D_{1}}
$$

because this is the endogenously derived return on deposits made at $t=1$ in Section 5 with multiple banks. ${ }^{19}$ Since $c_{1}^{*}>1$ and $c_{2}^{*}<r$, equations (4) and (5) imply

$$
D_{1,2}<r
$$

The fraction of depositors withdrawing at $t=1$ is defined as $\lambda^{p}$, where $\lambda^{p} \geq \lambda$ and the superscript ' $p$ ' denotes these withdrawals as 'purchases.' I assume that late consumers do not withdraw at $t=1$ if they are indifferent. A bank run equilibrium in the singlebank model is called a "purchase run" and is defined as $\lambda^{p}>\lambda$. Since all payments are made internal to the bank, the bank cannot default. The sequential service constraint is inconsequential in this section, but it is applied in the multiple-bank model in Section 5 where a bank default is possible. Although the bank would not default in this section if there were a purchase run, the optimal consumer allocation would not obtain. Note that the consumers' optimal allocation $\left(c_{1}^{*}, c_{2}^{*}\right)$ and the efficient $\alpha^{*}$ and $\gamma^{*}$ are the same as in the real deposits banking model.

\footnotetext{
${ }^{19}$ Payments and accounts are modeled more formally in the clearinghouse model of Section 5.
} 
Market clearing and price determination occurs simultaneously with calculating internal accounts at the bank to determine if the entrepreneur defaults. A competitive market equilibrium for goods is defined as a solution $\left(P_{t}, q_{t}\right)$ for $t \in\{1,2\}$ that solves

$$
\begin{aligned}
P_{1} q_{1}\left(P_{1}\right) & \equiv \lambda^{p} D_{1} \\
P_{2} q_{2}\left(P_{2}\right) & \equiv\left(1-\lambda^{p}\right) D_{2},
\end{aligned}
$$

where $P_{t}$ is the price, $q_{t}=q_{t}^{S}$ is the goods clearing equilibrium condition and $q_{t}^{S}$ solves the entrepreneur's optimization problem given below. Prices equate the value of goods sold, $P_{t} q_{t}\left(P_{t}\right)$, to the quantity of money spent on goods, $\lambda^{p} D_{1}$ at $t=1$ and $\left(1-\lambda^{p}\right) D_{1}$ at $t=2$. Solving for prices in (8) and (9),

$$
\begin{aligned}
& P_{1}=\frac{\lambda^{p} D_{1}}{q_{1}} \\
& P_{2}=\frac{\left(1-\lambda^{p}\right) D_{2}}{q_{2}} .
\end{aligned}
$$

The prices in a period is equal to money spent divided by goods for sale, corresponding to a simple version of the quantity theory of money. After market clearing, $q_{t}\left(P_{t}\right)$ is delivered to depositors purchasing goods.

In the case of a bank run by all late depositors, $\lambda^{p}=1$. The entrepreneur does not sell any goods at $t=2$ because if he did, $P_{2}$ would be zero. Hence, $P_{2}\left(\lambda^{p}=1\right)=\frac{0}{0}$ is undefined. Without loss of generality, I define $P_{2}^{1} \equiv P_{2}\left(\lambda^{p}=1\right)$, and assume $P_{2}^{1} \in(0, \infty) .{ }^{20}$

\section{Single-Bank Results}

Here I examine the entrepreneur's and consumers' problems. The entrepreneur's optimization problem is to maximize his profit subject to repaying his loan, which determines the relative amount of goods sold in each period. I first show that there are no purchase runs. Then the zero profit condition is imposed to determine prices and I show the optimal consumer allocation obtains.

\footnotetext{
${ }^{20}$ If any zero-mass set of late depositors were to withdraw at $t=2$, spending a zero-mass amount of money to buy goods, the entrepreneur would be indifferent to selling them any zero-mass amount of goods. The resulting price could be any positive, finite amount. The proof of Lemma 2 below shows that for $\lambda^{p}=1$, any $P_{2}^{1} \in(0, \infty)$ is consistent with the entrepreneur's choice of $q_{2}^{S}=0$ such that the first order conditions of the entrepreneur's optimization hold.
} 


\subsection{Entrepreneur Optimization}

The entrepreneur chooses $q_{1}^{S}\left(P_{1}\right)$ and $q_{2}^{S}\left(P_{2}\right)$, subject to repaying $K_{1}$ and $K_{2}$, taking prices as given. The market clearing equilibrium condition $q_{t}=q_{t}^{S}$ for $t \in\{1,2\}$ is then imposed.

First, I show the entrepreneur never defaults. The entrepreneur can always repay $K_{1}$ because it is set equal to the amount early consumers withdraw $\lambda D_{1}$ to purchase goods, seen from (6), (2) and (4). Consider the case of $q_{1}^{S}>0$. Substituting the equilibrium condition $q_{1}=q_{1}^{S}$ in the definition of $P_{1}$ and rearranging, the $q_{1}^{S} P_{1}$ revenues received by the entrepreneur at $t=1$ equal $\lambda^{p} D_{1} \geq K_{1}$. Next consider the case of $q_{1}^{S}=0$. This implies $P_{1}=\infty$, which means money is worthless and consumers are indifferent between paying money or not in the market since they receive no goods regardless. I assume that when consumers are indifferent they do not pay money, so the entrepreneur has to sell $q_{1}^{S}>0$ to not default. ${ }^{21}$

The entrepreneur can always repay $K_{2}$ as well. $K_{2}$ is set equal to the amount of withdrawals that late consumers spend on goods $(1-\lambda) D_{2}$ if they all withdraw at $t=2$, seen from (7), (3) and (5). If late consumers withdraw any money at $t=1$, it is spent on goods at $t=1$ and ends up as excess revenues that the entrepreneur receives and holds as deposits. The entrepreneur receives on this sum the return $D_{1,2}$ that any earlywithdrawing late consumers implicitly forgo. The entrepreneur's revenues at $t=2$ total

$$
\begin{aligned}
q_{2}^{S} P_{2}+\left(q_{1}^{S} P_{1}-K_{1}\right) D_{1,2} & =\left(1-\lambda^{p}\right) D_{2}+\left(\lambda^{p}-\lambda\right) D_{1} D_{1,2} \\
& =K_{2} .
\end{aligned}
$$

On the LHS, the first term is the entrepreneur's revenues from $t=2$ sales of goods, and the second term is the entrepreneur's return on $t=1$ deposits. Imposing the equilibrium condition $q_{t}=q_{t}^{S}$ and substituting for prices from (10) and (11) gives the RHS of (12), which equals $K_{2}$.

Equation (12) implies $q_{1}^{S}$ and $q_{2}^{S}$ cannot be independently chosen by the entrepreneur. Rearranging the equation, the choice of $q_{1}^{S}$ determines

$$
q_{2}^{S}=\frac{K_{2}+D_{1,2} K_{1}}{P_{2}}-q_{1}^{S} D_{1,2} \frac{P_{1}}{P_{2}}
$$

\footnotetext{
${ }^{21}$ Formally, $\left.q_{t}^{S} P_{t}\right|_{q_{t}^{S}=0} \equiv 0$ for $t \in\{1,2\}$.
} 
that is required to repay $K_{2}$. The entrepreneur's profit at $t=2$ is

$$
\widehat{q}_{2}^{S}-q_{2}^{S}
$$

where $\widehat{q}_{2}^{S}$ is the entrepreneur's total available goods at $t=2$, equal to the goods from storage, liquidation and investment returns minus the goods sold at $t=1$ :

$$
\widehat{q}_{2}^{S} \equiv 1-\alpha+\gamma s+(\alpha-\gamma) r-q_{1}^{S}
$$

The entrepreneur's optimization can be considered as his choice of how many goods to sell at $t=1$ relative to $t=2$ to maximize profits. Specifically, the entrepreneur chooses $q_{1}^{S}$ and $\gamma$. After substituting for $\widehat{q}_{2}^{S}$ and $q_{2}^{S}$ from (15) and (13) into (14), the maximization of the entrepreneur's profit (14) can be written as

$$
\begin{array}{ll}
\max _{q_{1}^{S}, \gamma} & {\left[1-\alpha+\alpha r-\gamma(r-s)-q_{1}^{S}\left(1-D_{1,2} \frac{P_{1}}{P_{2}}\right)-\frac{K_{2}+D_{1,2} K_{1}}{P_{2}} \mid \lambda^{p}\right]} \\
\text { s.t. } & q_{1}^{S} \leq 1-\alpha+\gamma s \\
& \gamma \leq \alpha,
\end{array}
$$

with the requirement that $q_{1}^{S}$ and $\gamma$ are nonnegative. The first constraint (16b) says that $\widehat{q}_{1}^{S} \equiv 1-\alpha+\gamma s$ is the most goods that can be sold at $t=1$. The second constraint (16c) says that $\alpha$ is the most invested goods that can be liquidated at $t=1$. Since $P_{1}$ and $P_{2}$ reflect $\lambda^{p}$, the entrepreneur's maximization problem is written as conditional on $\lambda^{p}$. I can now formally prove that the entrepreneur never defaults.

Lemma 1. The entrepreneur never defaults on repaying $K_{1}$ and $K_{2}$.

Proof. See Appendix.

Next, I examine the first order condition from the entrepreneur's optimization, which gives insight into how market prices prevent a purchase run. The entrepreneur's choices imply that $P_{1}$ is always greater or equal to discounted $P_{2}$ regardless of $\lambda^{p}$.

The first order condition (40) is restated from the proof of Lemma 1:

$$
D_{1,2} \frac{P_{1}}{P_{2}}=1+\theta_{1}
$$

where $\theta_{1}$ is the nonnegative Lagrange multiplier associated with the feasibility constraint 
(16b) on $q_{1}^{S}$. One plus $\theta_{1}$ represents the $t=2$ shadow value of selling a marginal good at $t=1$ relative to at $t=2$. The first order condition can be written in terms of marginal revenues. Since $\theta_{1} \geq 0$,

$$
P_{1} \geq \frac{P_{2}}{D_{1,2}}
$$

The entrepreneur attempts to equate discounted marginal revenues from sales at $t=1$ and at $t=2$. The LHS of (18) is the entrepreneur's marginal revenue $P_{1}$ of selling additional goods at $t=1$, whereas the RHS is the entrepreneur's marginal revenue $P_{2}$ discounted to $t=1$ by $D_{1,2}$ of selling additional goods at $t=2$. The inequality is due to the asymmetry between selling an additional good at $t=1$ versus at $t=2$. The discounted $t=2$ price of goods is never greater than the $t=1$ price of goods. If discounted $P_{2}$ were greater than $P_{1}$, the entrepreneur would store goods over from $t=1$ to sell at $t=2$. An increase (decrease) in $q_{1}\left(q_{2}\right)$ would drive $P_{1}\left(P_{2}\right)$ higher (lower), until $P_{1}=\frac{P_{2}}{D_{1,2}}$.

Conversely, suppose $\lambda^{p}$ were to increase due to a purchase run, driving up $P_{1}$ above discounted $P_{2}$. The entrepreneur would have to liquidate investments to sell more goods at $t=1$. The entrepreneur's first order condition under $\gamma>0$ is:

$$
s P_{1}=r \frac{P_{2}}{D_{1,2}} .
$$

The LHS (RHS) gives the discounted marginal revenues from selling an additional good at $t=1(t=2) . P_{1}$ is greater than discounted $P_{2}$ by the marginal rate of transformation $\frac{r}{s}$ from not liquidating an invested good, implying (18) does not bind if $\gamma>0$.

\subsection{Consumer Optimization}

The late consumers' problem is to choose whether to withdraw and purchase goods at $t=1$ or $t=2$. To analyze a late consumer's decision when to withdraw, I compare his real consumption $\frac{D_{t}}{P_{t}}$ from withdrawing and purchasing goods at $t=1$ versus at $t=2$.

A late consumer is better off withdrawing and purchasing goods at $t=1$ if and only if

$$
\frac{D_{1}}{P_{1}}>\frac{D_{2}}{P_{2}}
$$

However, the entrepreneur's first order condition (18) can be expressed as $\frac{D_{1}}{P_{1}} \leq \frac{D_{2}}{P_{2}}$, so (20) never holds. Hence, a late consumer never wants to run the bank to purchase goods. 
Proposition 2. There is no purchase run in the unique Nash equilibrium of the late consumers' problem of the single-bank model, given by $\lambda^{p}=\lambda$, which is an equilibrium in dominant strategies.

Proof. See Appendix.

To explain, a late consumer only wants to run the bank if, rewriting (20), $P_{1}<\frac{P_{2}}{D_{1,2}}$, or $P_{1}$ is low relative to $P_{2}$. This would mean that a relative abundance of goods is for sale at $t=1$. But if $P_{1}$ is low, the entrepreneur would shift selling goods from $t=1$ to $t=2$, driving $P_{1}$ up until $P_{1} \geq \frac{P_{2}}{D_{1,2}}$. The late consumer never has to run the bank at $t=1$ to purchase goods because the market always provides goods for patient depositors at $t=2$. Thus the no purchase run result is a unique equilibrium. Moreover, the preference by the late consumer to withdraw and purchase goods at $t=2$ according to $\frac{D_{2}}{P_{2}} \geq \frac{D_{1}}{P_{1}}$ holds by (18) for all $\lambda^{p}$. The no purchase run outcome is an equilibrium in dominant strategies. Furthermore, I do not need to make any assumptions regarding the late consumers' beliefs or symmetry of actions.

This is in important contrast to Diamond-Dybvig. Banks are fragile in DiamondDybvig because the no bank run outcome is a Nash equilibrium that depends on coordinated beliefs that other late consumers do not run. A shift in beliefs that other late consumers will run triggers the bank run equilibrium. In Diamond-Dybvig, the greater the number of late consumers that run the bank, the less the bank can pay out in goods at $t=2$, and so the greater the desire for a marginal late consumer to run. In this paper, since goods are sold by the market, a late consumer prefers to withdraw at $t=2$ even if other late consumers run the bank. In fact, the greater the number of late consumers who run the bank, the higher is $P_{1}$ (lower is $P_{2}$ ) and the lower is consumption $\frac{D_{1}}{P_{1}}$ at $t=1$ (higher is consumption $\frac{D_{2}}{P_{2}}$ at $t=2$ ). The price mechanism rations goods to depositors who run, ensuring an even greater desire of a marginal late consumer not to run.

\subsection{Optimal Allocation}

It remains to be shown that the allocation for consumers is the optimal one of $\left(c_{1}^{*}, c_{2}^{*}\right)$ from the planner's problem. The relative quantities sold by the entrepreneur in each period were solved for above. Now I find the actual quantities that the entrepreneur sells. The zero profit condition for the entrepreneur imposes that the entrepreneur profit $\widehat{q}_{2}^{S}-q_{2}^{S}$ equals zero in equilibrium. 
The optimal consumer allocation is achieved if there is no liquidation of invested goods at $t=1$ and no storage of current goods from $t=1$ to $t=2$. This means that all current goods are sold at $t=1, q_{1}=1-\alpha$, and all returns from invested goods are sold at $t=2$, $q_{2}=\alpha r$. By substituting these quantities into prices in (10) and (11), where $\lambda^{p}=\lambda$, prices in the optimal outcome are $P_{1}=P_{2}=1$.

To see that the optimal allocation is achieved by the market, first consider the contrary case that the entrepreneur would store current goods at $t=1$. The entrepreneur would never liquidate invested goods if he were storing goods at $t=1$, so $\gamma=0$. Also, the entrepreneur would sell all current goods at $t=1$ if $P_{1}>\frac{P_{2}}{D_{1,2}}$, so storage of current goods at $t=1$ implies (18) binds. Restated, storage at $t=1$ implies that the constraint on $q_{1}^{S}$, (16b), does not bind, so $\theta_{1}=0$ in (17) and

$$
P_{1}=\frac{P_{2}}{D_{1,2}}
$$

Storage at $t=1$ implies a decrease of $q_{1}$ and an increase of $q_{2}$, driving prices from the optimal outcome of $P_{1}=P_{2}=1$ to $P_{1}>1, P_{2}<1$. But this contradicts (21): marginal discounted revenues are not equated between $t=1$ and $t=2$. This shows that the entrepreneur does not store goods at $t=1$.

Second, consider the contrary case of liquidation of invested goods. This implies the entrepreneur is subject to the first order condition (19). Liquidation implies an increase of $q_{1}$ and a decrease of $q_{2}$, driving prices from the optimal outcome of $P_{1}=P_{2}=1$ to $P_{1}<1, P_{2}>1$. In (19), the LHS marginal revenues from liquidating and selling goods at $t=1$ are less than $s$, while the RHS discounted marginal revenues from selling returns from the invested goods at $t=2$ are greater than one, since $D_{1,2}<r$. This contradicts (19): marginal discounted revenues are not equated between $t=1$ and $t=2$. Thus, the entrepreneur does not liquidate invested goods.

Proposition 3. The allocation in the unique market equilibrium of the single-bank model is the consumers' optimal consumption $\left(c_{1}^{*}, c_{2}^{*}\right)$.

Proof. See Appendix.

This result also implies that nominal deposits are a Pareto optimal improvement over real deposits. Consumers receive optimal consumption with no risk of bank runs when they hold nominal deposits. If consumers were to hold real deposits, they would be exposed 
to the risk of bank runs and suboptimal consumption. If a second bank were to compete for deposits at $t=0$ by offering real demand deposits against the original bank offering nominal demand deposits, consumers would all deposit at the original bank and nominal deposits would be the unique equilibrium.

With the assumption of a zero profit condition imposed ex-post on the entrepreneur in this model, prices are determined and the consumers' optimal allocation obtains. The robustness of this assumption is studied in the Appendix. Dropping this assumption allows for potential price indeterminacy, but this does not effect the result of no bank runs in the single-bank model or the multiple-bank model below. Rather, different price equilibria can lead to transfers between consumers and the entrepreneur. These equilibria are not Pareto-ranked because there are no ex-ante or ex-post inefficiencies. In the Appendix, I consider a zero-profit condition assumed ex-ante rather than imposed ex-post. The bank can ensure that prices are determined by adjusting the entrepreneur's loan repayments, which results in the consumers' ex-ante optimal allocation. Alternatively, the application of a stable equilibrium concept introduced in the Appendix achieves the same result.

\section{Clearinghouse in a Multiple-Bank Model}

\subsection{Clearinghouse Model}

In this section, I extend the single-bank model to a multiple-bank model. This allows for examining "redeposit runs," in which depositors run their bank by withdrawing and redepositing at a different bank. A second bank, labelled 'bank B', allows for $t=1$ payments and redeposits to accounts outside of the original bank, now labeled 'bank A' ${ }^{22}$

At $t=1$, early consumers withdraw to purchase goods. Late consumers may now withdraw early either to purchase goods or to redeposit funds to bank B. I define $\lambda^{w} \geq \lambda^{p}$ as the fraction of consumers who withdraw at $t=1$, where the superscript ' $w$ ' denotes 'total withdrawals' at $t=1$. The fraction $\lambda^{w}-\lambda^{p}$ of consumers withdraw and redeposit at bank B. A bank run equilibrium is redefined as $\lambda^{w}>\lambda$, which can be due to either a purchase run, $\lambda^{p}>\lambda$, or due to a "redeposit run," defined as $\lambda^{w}>\lambda^{p}$. Bank B offers return $D_{2}^{B}$ on deposits $I_{2}^{B}$ made at $t=1$ by redepositors and/or the entrepreneur. Bank B is owned by

\footnotetext{
${ }^{22}$ Bank B may represent multiple banks and for simplicity does not offer deposits and loans itself at $t=0$. If it did, it would also have the potential for runs with its late consumers purchasing goods or redepositing to bank $\mathrm{A}$. The results are unchanged, in that interbank lending implies that no bank would fail and there would be no runs in equilibrium.
} 
its $t=1$ depositors and acts to maximize their $t=1$ utility. For simplicity, I assume bank A does not take new deposits from the entrepreneur at $t=1$. The entrepreneur receives and makes payments and holds deposits at an account with bank $\mathrm{B}$ at $t \in\{1,2\}$. If late consumers are indifferent, they keep their deposits at bank A.

A clearinghouse budget constraint for each bank in period $t \in\{1,2\}$ is based on a "payment-in-the-same-period" constraint, in contrast to the traditional "cash-in-advance" constraint. Payments are made between banks A and B within a clearinghouse under deferred net settlement, explained as follows. ${ }^{23}$ A clearinghouse is an intraperiod "balance sheet" with accounts for banks A and B. Banks A and B also have internal accounts for depositors and the entrepreneur, separate from the clearinghouse accounts. At the start of $t \in\{1,2\}$, both banks start at zero balances. A payment debits the paying bank's account and credits the receiving bank's account, and additionally debits or credits internal bank accounts as appropriate. A bank can make any amount of payments during a period and so carry a negative intraperiod clearinghouse balance. Payment credits and debits are provisional until settled at the end of the period.

At $t \in\{1,2\}$, depositor withdrawals for redeposits and purchases are paid from bank A to bank B. Consumers with deposits at bank B withdraw at $t=2$ to purchase goods, so bank B only adjusts internal accounts. Withdrawals to purchase goods are also recorded as a demand schedule with a Walrasian auctioneer. The entrepreneur simultaneously submits a supply schedule $q_{t}^{S}$ to the auctioneer. The entrepreneur repays $K_{t}$ on his loan to bank A. At $t=1$, Bank B makes a take-it-or-leave-it loan offer of an amount $F \geq 0$ at a return of $D_{2}^{F}$ (corresponding to the U.S. federal funds rate) to bank A. Bank A chooses action $\phi \in\{0,1\}$, where $\phi=1(\phi=0)$ corresponds to 'accept' ('reject'). If bank A accepts, it repays $D_{2}^{F} F$ at $t=2$.

At the end of the period, a bank with a net negative balance owes this amount in central bank currency to the other bank. Since banks have no currency, they must finish with a zero net balance for their provisional payments to "settle" and take effect. If a bank's payments do not settle, only the largest partial amount of its payments, calculated first according to the seniority of the claim, and second according to the sequential order in which they were made during the period, that do net out to zero are called "settled."

\footnotetext{
${ }^{23}$ While this model represents a private clearinghouse, such as CHIPS under its former deferred net settlement system, the model could be adjusted to represent a real-time gross settlement clearinghouse operated by a central bank, such as the Federal Reserve's Fedwire, without changing the results.
} 
All payments that do not settle are unwound and defaulted upon by the bank. ${ }^{24}$

At the end of the period the following occurs simultaneously: clearing in all markets and the determination of prices, netting and settlement of payments through the clearinghouse and calculating internal accounts at banks A and B. The market for monetary balances held overnight by banks clears through the price $D_{2}^{F}$ chosen by bank B at $t=1$ in (30) below. The market for goods clears through the price $P_{t}$ in $t \in\{1,2\}$ determined by the market equilibrium conditions (24) and (25) below. Bank B's budget constraint to settle payments is given by (29), (31) and (32) below. First, I examine bank A's budget constraint to settle payments in each period:

$$
\begin{array}{rr}
t=1: & \lambda^{w} \delta_{1} D_{1} \leq \phi F+\kappa_{1} K_{1}+\kappa_{1,2} K_{2} \\
t=2: & \left(1-\lambda^{w}\right) \delta_{2} D_{2}+\phi F \delta_{2}^{F} D_{2}^{F} \leq \kappa_{2}\left(1-\kappa_{1,2}\right) K_{2} .
\end{array}
$$

Define $\kappa_{t} \in[0,1]$ as the fraction that settles on the entrepreneur's loan repayment of $K_{t}$ in period $t$. If $\kappa_{t}<1$, the entrepreneur defaults and must sell all goods, including any invested goods that must first be liquidated. The variable $\delta_{t}^{i} \in[0,1]$ is defined as the fraction that actually settles of the contracted return $D_{t}^{i}$ due, where $i \in\{A, B, F\}$ and the notation $i=A$ is suppressed to conform with the single-bank model. If $\delta_{t}^{i}<1$, the bank paying $D_{t}^{i}$ defaults at period $t$. If bank $\mathrm{A}$ were to default at $t=1$, it liquidates its long term loan to the entrepreneur only as a last resort by calling enough of it for repayment to try not to default. Define $\kappa_{1,2} \in[0,1]$ as the fraction of $K_{2}$ called by bank A that is due to be repaid at $t=1$ and settles. This leaves $\left(1-\kappa_{1,2}\right) K_{2}$ due at $t=2$. This implies that $\delta_{1}<1$ only if $\kappa_{1,2}=1$. Furthermore, $\kappa_{1,2}>0$ implies $\alpha=1$.

In (22), the RHS loan from bank B and the loan repayment from the entrepreneur that settles to bank $\mathrm{A}$ at $t=1$ must be greater than or equal to the LHS deposits repaid and settled by bank A to early withdrawers. In (23), the RHS loan repayment from the entrepreneur that settles to bank $\mathrm{A}$ at $t=2$ must be greater than or equal to the LHS deposits repaid and settled by bank A to late withdrawers. If a bank defaults, the amount of withdrawal payments that do settle is $\delta_{t}^{i}$, where $i \in\{A, B, F\}$. Because the clearinghouse rules give settlement to payments in the order they were made, the sequential service constraint holds. Interbank loans have a junior claim to demand deposits, which

\footnotetext{
${ }^{24}$ The model abstracts away from risk within the payments system, since there is no risk to the receiving bank if a payment does not settle. Payments risk within a clearinghouse is an important issue and is studied in Rochet and Tirole (1996).
} 
implies $\delta_{2}<1$ only if $\delta_{2}^{F}=0 .^{25}$

A competitive market equilibrium for goods is defined as in the single-bank model, with the exception that (8) and (9) are replaced by

$$
\begin{aligned}
& P_{1} q_{1}\left(P_{1}\right) \equiv \lambda^{p} \delta_{1} D_{1} \\
& P_{2} q_{2}\left(P_{2}\right) \equiv\left(1-\lambda^{w}\right) \delta_{2} D_{2}+\left(\lambda^{w}-\lambda^{p}\right) \delta_{1} D_{1} \delta_{2}^{B} D_{2}^{B},
\end{aligned}
$$

where $q_{t}^{S}$ solves the entrepreneur's optimization. Prices that clear the goods market are now solved as

$$
\begin{aligned}
P_{1} & =\frac{\lambda^{p} \delta_{1} D_{1}}{q_{1}} \\
P_{2} & =\frac{\left(1-\lambda^{w}\right) \delta_{2} D_{2}+\left(\lambda^{w}-\lambda^{p}\right) \delta_{1} D_{1} \delta_{2}^{B} D_{2}^{B}}{q_{2}},
\end{aligned}
$$

where the numerators reflect the settled payments for purchasing goods by consumers at each period. The settled amount the entrepreneur repays on its loan at $t=1$ is $\kappa_{1} K_{1}+\kappa_{1,2} K_{2}$, where $\kappa_{1} \equiv \frac{\min \left\{\lambda D_{1}, \lambda^{p} \delta_{1} D_{1}\right\}}{K_{1}}$, and at $t=2$ is $\kappa_{2}\left(1-\kappa_{1,2}\right) K_{2}$, where

$$
\kappa_{2} \equiv \frac{\min \left\{\left(1-\kappa_{1,2}\right) K_{2},\left(1-\lambda^{w}\right) \delta_{2} D_{2}+\left[\left(\delta_{1} \lambda^{w}-\kappa_{1} \lambda\right) D_{1}-\kappa_{1,2} K_{2}\right] \delta_{2}^{B} D_{2}^{B}\right\}}{\left(1-\kappa_{1,2}\right) K_{2}}
$$

The entrepreneur delivers $q_{t}\left(P_{t}\right)$ goods at period $t \in\{1,2\}$ to purchasers whose payments settle.

\subsection{Multiple-Bank Results}

I first examine the interbank borrowing and lending problems of the banks. In order to maximize the return on its $t=1$ deposits, bank B would always prefer to lend any funds it has to bank A to capture part of the return bank A receives from its long term investments. Bank A can borrow fully from bank B and so does not default even if there were extensive early withdrawals. Then I examine the entrepreneur's and consumers' problems. Since bank A never defaults, the optimizations collapse to those from the single bank model.

\footnotetext{
${ }^{25}$ This is necessary so that the second bank cannot expropriate late consumers who do not withdraw at $t=1$ when it lends to the original bank, and so it is a natural condition of the demand deposit contract that the original bank includes at $t=0$ in order to maximize $t=0$ depositors' welfare. The U.S. created a national depositor-preference law giving depositors priority on the assets of failed banks over other claimants as part of the Omnibus Budget Reconciliation Act of 1993 following the FDICIA deposit insurance reforms in 1991.
} 
There are no redeposit runs or purchase runs, and the optimal allocation obtains.

\subsubsection{Interbank Lending}

Bank A's problem is to attempt not to default. The bank has to repay deposits at $t \in$ $\{1,2\}$. It chooses whether to accept an interbank loan and then has to repay that as well. The bank's optimization is

$$
\begin{aligned}
\max _{\phi, \delta_{1}, \delta_{2}} & \delta_{1}(\phi)+\delta_{2}(\phi) \\
\text { s.t. } & (22)
\end{aligned}
$$

Since $\delta_{1}<1$ implies $\delta_{2}=0$, bank A chooses $\phi, \delta_{1}$ and $\delta_{2}$ based on maximizing payouts first to early withdrawers through $\delta_{1}$, and second to late withdrawers, through $\delta_{2}$, subject to its budget constraints (22) and (23).

Bank B's problem is to maximize the return it pays its $t=1$ depositors. Deposits received by bank $\mathrm{B}$ at $t=1$ are

$$
\begin{aligned}
I_{2}^{B} & =\left(\lambda^{w}-\lambda^{p}\right) \delta_{1} D_{1}+P_{1} q_{1}-\kappa_{1} K_{1}-\kappa_{1,2} K_{2} \\
& =\left(\delta_{1} \lambda^{w}-\kappa_{1} \lambda\right) D_{1}-\kappa_{1,2} K_{2} \\
& \geq 0
\end{aligned}
$$

The first term on the RHS of (29) is the quantity of redeposits received from late consumers withdrawing at $t=1$. The remaining terms are the quantity of deposits received from the entrepreneur, equal to the excess of the entrepreneur's revenues in the first period beyond his loan repayment. Since there is no further uncertainty, bank B's optimization is to 
maximize the return $\delta_{2}^{B} D_{2}^{B}$ it pays depositors.

$$
\begin{aligned}
\max _{F, D_{2}^{F}, \delta_{2}^{B} D_{2}^{B}} & \delta_{2}^{B} D_{2}^{B} \\
\text { s.t. } & \phi F \leq I_{2}^{B} \\
& I_{2}^{B} \delta_{2}^{B} D_{2}^{B} \leq \phi F \delta_{2}^{F} D_{2}^{F} \\
& \delta_{2}^{F} D_{2}^{F} \geq 1
\end{aligned}
$$

Equations (31) and (32) are Bank B's budget constraints at $t=1$ and $t=2$, respectively. The maximum return that bank $\mathrm{B}$ can repay on deposits is given from (32) by

$$
\delta_{2}^{B} D_{2}^{B} \leq \frac{\phi F \delta_{2}^{F} D_{2}^{F}}{I_{2}^{B}}
$$

Equation (33) is the rationality constraint for bank B to lend. Equations (31) and (34) show that bank B prefers to lend out as much as possible of the deposits it receives, at the highest return that bank A will accept and be able to pay and settle, given by $\phi \delta_{2}^{F} D_{2}^{F}$, in order to pass on the maximum return it can to its depositors. Equations (22) and (23) are Bank A's budget constraints, which constrain the amount that bank B can collect as return on its loan.

Bank A always accepts the loan because if $F>0$, bank A defaults without it. The only amount bank A needs to borrow is the $F=\lambda^{p} D_{1}-\lambda D_{1}$ offered by bank B. This is the amount that late consumers withdraw at $t=1$ for redeposits and purchases that end up deposited at bank B by the redepositors and entrepreneur. Bank A can always pay a return up to $\frac{D_{2}}{D_{1}}$ on the loan it needs since this is the implicit rate between $t=1$ and $t=2$ that it would have paid to late consumers if they withdrew at $t=2$ instead of earlier. Bank A cannot pay more since it just breaks even when paying that rate. If bank B were to offer $D_{2}^{F}>\frac{D_{2}}{D_{1}}$, bank A would accept but just default to bank B on the excess, resulting in $\delta_{2}^{F} D_{2}^{F}=\frac{D_{2}}{D_{1}}$. This would not effect any bank $\mathrm{A}$ depositors withdrawing at $t=2$ since interbank loans are junior to deposits. ${ }^{26}$ Thus, $D_{2}^{B}=D_{1,2}^{F}=\frac{D_{2}}{D_{1}}$ is the deposit rate at

\footnotetext{
${ }^{26}$ If interbank loans were senior to deposits, bank B would accept redeposits from late consumers and then demand $\delta_{2}^{F} D_{2}^{F}>\frac{D_{2}}{D_{1}}$ and extort remaining bank A late consumers. All late consumers would redeposit, implying a full run and failure of bank A. This occurs due to bank B's bargaining power. If the interbank
} 
$t=1 .^{27}$

Lemma 2. Bank $B$ lends $F=\left(\lambda^{w}-\lambda\right) D_{1}$ to bank $A$ at a return of $D_{2}^{F}=D_{2}^{B}=\frac{D_{2}}{D_{1}}$. There are no defaults by bank $A$, bank $B$ or the entrepreneur and no calls on the entrepreneur's loan:

$$
\begin{aligned}
\delta_{2}^{F} & =\delta_{1}=\delta_{2}=\delta_{2}^{B}=\kappa_{1}=\kappa_{2}=1 \\
\kappa_{1,2} & =0 .
\end{aligned}
$$

Proof. See Appendix.

\subsubsection{Entrepreneur and Consumer Optimizations}

The entrepreneur's optimization problem and the goods market outcome are identical to those in the single-bank model. Since there are no defaults and $D_{2}^{B}=D_{1,2}=\frac{D_{2}}{D_{1}}$, prices given by (26) and (27) are unchanged from prices given in the single-bank model by (10) and (11), respectively. If there is a redeposit run, bank A pays the implicit return $\frac{D_{2}}{D_{1}}$, which redepositors forgo, instead as a return on the interbank loan to bank B, which pays it to the redepositors. Thus, the amount of money spent on purchases at $t=2$ is unaffected by redeposits. Hence, the entrepreneur's maximization problem is identical to (16) in the single-bank problem. The entrepreneur's first order condition (18) continues to hold.

The late consumers' optimization is expanded to choose whether to run the bank at $t=1$, and either redeposit or purchase goods; or to withdraw and purchase goods at $t=2$. I compare the real consumption from the three options. A late consumer is better off withdrawing and redepositing at $t=1$ if and only if it is preferred to purchasing goods at $t=2$,

$$
\frac{\delta_{1} D_{1} \delta_{2}^{B} D_{2}^{B}}{P_{2}}>\frac{\delta_{2} D_{2}}{P_{2}}
$$

market were dispersed among many banks who were price-takers as consumers are, bank A would not have runs. To the extent the interbank market can act strategically, the seniority of demand deposits is important.

${ }^{27}$ Bank B would choose to lend fully to bank A even if lending to new entrepreneurs with new investment projects were possible. Lending to bank A is optimal for bank B and social welfare since it provides the greatest possible one-period nominal return of $\frac{D_{2}}{D_{1}}$ to bank B and real return of $\frac{r}{s}$ to society from continuing the invested goods instead of liquidating them. 
and preferred to purchasing goods at $t=1, \frac{\delta_{1} D_{1} \delta_{2}^{B} D_{2}^{B}}{P_{2}}>\frac{\delta_{1} D_{1}}{P_{1}}$. A late consumer is better off withdrawing and purchasing goods at $t=1$ if and only if it is preferred to purchasing goods at $t=2$,

$$
\frac{\delta_{1} D_{1}}{P_{1}}>\frac{\delta_{2} D_{2}}{P_{2}}
$$

and preferred to redepositing at $t=1$,

$$
\frac{\delta_{1} D_{1}}{P_{1}}>\frac{\delta_{1} D_{1} \delta_{2}^{B} D_{2}^{B}}{P_{2}}
$$

Bank B cannot pay a higher return on deposits between $t=1$ and $t=2$ than bank $\mathrm{A}$, so $D_{2}^{B}=\frac{D_{2}}{D_{1}}$ and the LHS of (35) equals $\frac{D_{2}}{P_{2}}$. Bank A never defaults, so $\delta_{2}=1$ and the RHS of (35) equals $\frac{D_{2}}{P_{2}}$. Hence, (35) does not hold, so late consumers never withdraw early to redeposit at bank $B$.

This is again in contrast to Diamond-Dybvig. In that paper, the more late consumers who run the bank, the likelier it will fail and the more that a marginal late consumer prefers to run. In the current study, the early withdrawals by others do not impact the ability of a marginal late consumer to withdraw at $t=2$. Thus, there are no possible beliefs to trigger a redeposit run.

No defaults and $D_{2}^{B}=\frac{D_{2}}{D_{1}}$ imply that the late consumer's criteria to withdraw at $t=1$ to purchase goods, (36) and (37), collapse to (20), the criteria in the single-bank model. From the single-bank model, the entrepreneur's first order condition (18) implies (20) does not hold, so the late consumers do not withdraw early to purchase goods.

Proposition 4. There is no bank run in the unique Nash equilibrium of the late consumers' problem of the multiple-bank model, given by $\lambda^{w}=\lambda^{p}=\lambda$, which is an equilibrium in dominant strategies. The allocation in the unique market equilibrium is the consumers' optimal consumption $\left(c_{1}^{*}, c_{2}^{*}\right)$.

Proof. See Appendix.

\section{Sequential Market}

An important reason why real demand deposit contracts allow bank runs in DiamondDybvig is that the contract is not contingent on the realized state of $\lambda^{p}$. The assumption of a sequential-service constraint implies that the deposit contract cannot depend on $\lambda^{p}$ 
as the first depositors withdraw at $t=1$ because $\lambda^{p}$ is not known until $\lambda^{p}$ depositors have already withdrawn. Thus, demand deposits repay a non-contingent fixed amount of consumption goods $c_{1}^{*}$ to each depositor who withdraws at $t=1$ until all goods are paid out.

In the nominal contracts model, nominal payouts by the bank are also not contingent on $\lambda^{p}$. The fixed payout (in money) of the deposit contract and the sequential service constraint are strictly adhered to. However, real consumption $\frac{\delta_{1 t} D_{1}}{P_{1}}=\frac{q_{1}}{\lambda^{p}}$ to the depositor withdrawing at $t=1$ is contingent on $\lambda^{p}$ through $P_{1}$. This is because the market for goods is assumed to be a centralized one-price Walrasian market. The price in the goods market is based on aggregate withdrawals at $t=1$ and is not determined until $\lambda^{p}$ is realized. Although the payout by the bank does not settle until $\lambda^{p}$ and $P_{1}$ are realized, the sequential service constraint is formally upheld by the bank because the monetary amount paid and settled on a withdrawal for a depositor does not depend on the withdrawals after him. The payment from the bank for a depositor withdrawal settles in full before the payment for the next depositor withdrawal settles.

However, this may not reflect the spirit of the sequential service constraint as interpreted by Wallace (1988). He requires that a withdrawer receives and consumes his real consumption before the next depositor withdraws, due to an assumption that consumers are physically isolated from each other and a liquidity shock at $t=1$ means that consumers need to consume immediately within the period rather than at the end of the period.

\subsection{Sequential Market Model}

The Wallace (1988) requirement for what I call his "sequential consumption constraint" may be easily met in the nominal contracts model with the introduction of a sequential market that replaces the centralized market in the multiple-bank model as follows. In $t=1$, depositors in a random order sequentially discover their early or late type and have the opportunity to sequentially withdraw and consume in that order. A consumer who discovers being an early type needs to withdraw and consume before the next consumer in the sequential order discovers his type and has an opportunity to withdraw. The late consumer's consumption $c_{2}$ is modified to equal goods he consumes in both $t=1$ and $t=2$.

Before a withdrawal, the competitive entrepreneur posts a price $P_{t}\left(\bar{\lambda}^{p}\right)$, where $\bar{\lambda}^{p}$ is the cumulative fraction of depositors who have purchased goods up to that point within 
period $t$. Bank B also posts a deposit rate $D_{2}^{B}$. Then a single depositor may withdraw to purchase goods or to redeposit. Bank A makes a payment to bank B for the withdrawal amount. If there is a purchase, the payment goes to the entrepreneur's account at bank B. The entrepreneur uses the funds to pay a portion of $K_{1}$ to bank $\mathrm{A}$ if the loan is outstanding, or else keeps the funds on deposit with bank B at $D_{2}^{B}$. Bank B may lend to bank A. Markets clear and clearinghouse payments are netted out and settled. Bank A's payment must settle before the bank makes a payment for the next depositor withdrawal, otherwise it defaults. If a purchase payment does settle, the entrepreneur delivers goods to the purchaser according to $P_{1}\left(\bar{\lambda}^{p}\right)$ and the depositor immediately consumes. The process repeats with the entrepreneur and bank B posting a new $P_{1}\left(\bar{\lambda}^{p}\right)$ and $D_{2}^{B}$, respectively, and the next depositor discovering his type and choosing whether to withdraw. The realization of $\lambda^{p}$ does not take place until the last depositor decides whether to withdraw at $t=1$, by which point all other earlier purchasers have consumed their purchases. At $t=2$, late consumers who have not yet purchased goods make purchase withdrawals from their bank and consume in a sequential random order in a similar fashion to withdrawals in $t=1$.

\subsection{Entrepreneur and Consumer Optimizations}

The outcome in this sequential market model is the same as that of the centralized market model in Section 5. The budget constraint and optimization problems for banks A and B are unchanged from the centralized market model in Section 5. The sequential payments for purchases, redeposits, entrepreneur loan repayments and interbank loans and repayments aggregate up in each period $t \in\{1,2\}$ and are equal to the equivalent lump-sum aggregate payments in the centralized market model. Bank B lends incrementally any amount needed by bank $\mathrm{A}$ at a rate of $\frac{D_{2}}{D_{1}}$. The entrepreneur repays its loan, and bank A does not default on deposits or interbank loans. This implies late consumers do not redeposit, so there is no redeposit run.

The question of if there is a purchase run is more subtle. Whether $\lambda^{p}=\lambda$ or $\lambda^{p}>\lambda$ is expected at the start of $t=1$, the entrepreneur's optimization problem is unchanged from the centralized market model. If a purchase run $\lambda^{p}>\lambda$ is expected, the entrepreneur

applies the first order condition under liquidation (19), s $P_{1}=r \frac{P_{1}}{D_{1,2}}$, to prices at $t=1$. 
Rearranging, this implies

$$
\begin{aligned}
\frac{D_{1}}{P_{1}} & =\frac{s D_{2}}{r P_{2}} \\
& <\frac{D_{2}}{P_{2}},
\end{aligned}
$$

a contradiction of the late consumers' optimization (20). Late consumers do not prefer to purchase goods early, so $\lambda^{p}=\lambda$ and there is no purchase run.

If $\lambda^{p}=\lambda$ is expected, the entrepreneur sets $P_{1}\left(\bar{\lambda}^{p}=\lambda\right)=P_{2}\left(\lambda^{p}=\lambda\right)=1$, and sells the $1-\alpha$ stored goods to the first $\lambda$ purchasers at $t=1$. If additional purchasers appear after the first $\lambda$ fraction, the entrepreneur posts a new $P_{1}\left(\bar{\lambda}^{p}>\lambda\right)$ to equalize discounted revenues between a marginal amount of invested goods sold (i) in liquidation for $s P_{1}\left(\bar{\lambda}^{p}>\lambda\right)$ at $t=1$, versus (ii) at full return for $r P_{2}\left(\bar{\lambda}^{p}>\lambda\right)$ at $t=2$. Equation (19) still holds, but with $P_{1}\left(\bar{\lambda}^{p}>\lambda\right)$ substituted in for $P_{1}$ as the price for marginal goods sold to a marginal purchaser at $t=1$. The new sequential market equilibrium equation that defines $P_{1}\left(\bar{\lambda}^{p}>\lambda\right)$ and replaces $(26)$ is

$$
\Delta \bar{q}_{1}^{S} P_{1}\left(\bar{\lambda}^{p}>\lambda\right) \equiv \Delta \bar{\lambda}^{p} D_{1}
$$

where $\Delta \bar{\lambda}^{p}$ is the size of the marginal purchaser and $\Delta \bar{q}_{1}^{S}=\Delta \bar{\gamma} s$ is the marginal goods sold from liquidating $\Delta \bar{\gamma}$ marginal invested goods. Since $\lambda^{p}$ is known at the start of $t=2$, the definition of $P_{2}(27)$ is unchanged and the entrepreneur posts a fixed $P_{2}$ throughout $t=2$.

Excess early purchases at $t=1$ do not end up changing $P_{2}$ from its value when there is no run: $P_{2}\left(\bar{\lambda}^{p}>\lambda\right)=P_{2}\left(\lambda^{p}=\lambda\right)=1$. This is because the loss from liquidating invested goods is fully borne by early purchasers who buy the liquidated invested goods. Substituting $P_{2}=1$ in (19),

$$
\begin{aligned}
P_{1}\left(\bar{\lambda}^{p}>\lambda\right) & =\frac{r}{s D_{1,2}} \\
& >1
\end{aligned}
$$

The consumption for these early purchasers is $\frac{s D_{1,2}}{r}$, compared with consumption for purchasers at $t=2$ of $D_{2}$. Since $P_{1}\left(\bar{\lambda}^{p}>\lambda\right)>P_{2}$ implies (20) does not hold, no late consumer would choose to purchase goods at $t=1$ after the first $\lambda$ fraction of depositors 
have purchased goods. Moreover, a late consumer who purchases goods among the first $\lambda$ fraction at $P_{1}\left(\bar{\lambda}^{p} \leq \lambda\right)=1$ is also worse off than purchasing goods at $P_{2}=1$ at $t=2$, according to (20). This is because late purchasers' consumption at $t=2$ is dependent on $P_{2}=1$ and so is unaffected by whether other late consumers run at $t=1$. Thus, there is no purchase run.

Proposition 5. There is no bank run in the unique Nash equilibrium of the late consumers' problem of the multiple-bank model with sequential markets, given by $\lambda^{w}=\lambda^{p}=\lambda$, which is an equilibrium in dominant strategies. The allocation in the unique market equilibrium is the consumers' optimal consumption $\left(c_{1}^{*}, c_{2}^{*}\right)$.

\section{Proof. See Appendix.}

The real consumption of each withdrawer at $t=1$ does not need to depend on the number of early withdrawers following him, as revealed in $\lambda^{p}$ by a centralized market price, for runs to be avoided. Rather, the sequential market ensures that the real consumption of each early withdrawer depends on only the number of withdrawers before him to ration excess early consumption and dissuade a run. Although the price for each transaction at $t=1$ is set based on perfect information of the number of prior purchasers, this could be relaxed. Withdrawers at $t=1$ could each purchase goods at $t=1$ from a random draw of an entrepreneur out of a continuum of informationally isolated entrepreneurs rather that from a single entrepreneur. Each individual entrepreneur would charge $P_{1}\left(\bar{\lambda}^{p}>\lambda\right)>1$ for any liquidated goods he sells and $P_{2}=1$ for $t=2$ sales. Thus, a late consumer would always be better off withdrawing at $t=2$.

\section{Discussion}

Demand deposits repayable in money achieve the no bank runs result, whereas deposits repayable in real goods allow for runs in Diamond-Dybvig. To interpret this result, I discuss the four features of money as payment in the model that prevents runs. Money is i) in the form of a liability claim, ii) which is denominated in a nominal unit of account, iii) the claim is a liability of the bank making the payment, and iv) is payable to banks who can coordinate lending.

Payment in the form of a real or nominal claim prevents redeposit runs. Instead, if payment is in goods, an interbank lending market with multiple banks does not suffice to 
prevent a redeposit run. Late consumers could withdraw goods from bank A at $t=1$ and redeposit at bank $\mathrm{B}$, but bank $\mathrm{A}$ would first have to liquidate invested goods to repay late consumers their withdrawal. Liquidation costs imply that bank A would default even if bank B were to lend to bank A. Thus bank B would not lend and redeposit runs could occur in equilibrium. Deposits repayable with claims on real goods, in which the claim is a liability of bank A and is redeemable on demand under a sequential service constraint, prevent redeposit runs. Late consumers could withdraw claims at $t=1$ and redeposit them at bank B. Bank B would lend the claims back to bank A, and bank A could repay bank $\mathrm{B}$ in goods at $t=2$. There would be no liquidation or default, so a run never starts.

However, real claims are not sufficient to eliminate all runs. If depositors believe that everyone is withdrawing and redeeming claims at $t=1$, bank $\mathrm{A}$ has to liquidate invested goods and will default. If real claims were the liability of the entrepreneur, a run for redemption on the entrepreneur also leads to liquidation and default. Claims denominated in a real unit of account have a fixed real value. ${ }^{28}$

Claims denominated in a nominal unit of account that are redeemable in the nominal numeraire by the end of the period, settled on a netting basis, have a flexible real value. This value is determined by prices in a market of goods for claims, which prevents purchases runs. In this paper, central bank currency is the nominal unit of account. ${ }^{29}$ If deposits were indexed to prices, deposits would have a real value instead of a nominal value and purchase runs could occur. Alternatively, if the central bank continued to set a fixed price in $t \in\{1,2\}$, money would have a real unit of account and purchase runs again could occur. For example, a central bank that sets a gold standard or pegs its currency could induce a run, in which a bank paying withdrawals in domestic money does not fail, but the central bank loses all reserves and has to devalue the currency.

The final features of money to prevent runs is that bank A pays a claim to bank $\mathrm{B}$ for depositor withdrawals, and the claim is a liability on bank A itself, which is "inside

\footnotetext{
${ }^{28}$ As in Diamond-Dybvig, in the centralized market model I take as given that bank deposits are paid on demand under a sequential service constraint. In the environment of the sequential market model in this paper, deposits paid on demand under a sequential service constraint are optimal features of the deposit contract, as shown by Wallace (1988).

${ }^{29} \mathrm{I}$ do not examine whether the clearinghouse could establish the nominal unit of account at $t=0$ instead of a central bank. This question is related to whether a central bank or clearinghouse is necessary to achieve efficiency in payments, examined in Green (1999a). Without either a central bank or clearinghouse unit of account, a competing bank paying inside money in its own self-defined nominal unit of account could overissue deposits and inflate money payments. I also do not address whether settlement should occur at the end of each period or only at the end of $t=2$. Koeppl et al. (2006) study a similar question of settlement frequency in a search model of payments.
} 
money," as opposed to a liability on the central bank, which is currency or "outside money." When the bank pays inside money, it pays a liability that the bank must settle in currency by the end of the period. Bank A can pay any amount of claims on itself for depositor withdrawals on demand, i.e. it has a perfectly elastic supply of its own liabilities, since the present value of its liabilities equals that of its assets. These claims are paid for withdrawals from bank A for purchases or redeposits through the clearinghouse to bank $\mathrm{B}$, which can lend them all back. Thus, the liability to pay currency at the end of the period nets out to zero.

Because bank A pays claims for withdrawals to bank B on behalf of depositors, bank $\mathrm{B}$ resolves the coordination problem of late depositors running bank A. However, Skeie (2004) shows that a bank run could occur instead due to a coordination problem of lending in the interbank market, if multiple banks that are informationally dispersed receive clearinghouse payments from bank A. Alternatively, a run could occur if the claim withdrawn on deposits is currency rather than inside money, due to depositor withdrawals and storage of currency outside of the banking system. A remedy for either run is for the central bank to lend currency, since the central bank can ensure an elastic supply of its own liabilities.

With no currency held in the model at $t \in\{1,2\}$, there is no need for creating an adhoc demand for holding money, which is required in other papers when money otherwise pays a lower return than other assets. Typical assumptions include a cash-in-advance constraint and the fiscal theory of money, which are both applied by Diamond and Rajan (2006); a loan injection and then extraction of currency by the central bank, which is applied by Allen and Gale (1998); and money in the utility function, used by Chang and Velasco (2000).

In this paper, at the beginning and end of each period $t \in\{1,2\}$, bank A's interperiod "balance sheet" liabilities (deposits and interbank loans) and assets (entrepreneur loans) are equal to each other on a present value basis. Any intraperiod monetary payments bank A makes are equal to payments received and net out. There is no need in the model for a supply of currency to be held between periods, which would receive a zero return, to use for making payments within periods.

The assumption of no outside money reserves in the model is abstract and intended to be parsimonious, to focus on the central issue of modern interbank payments and lending. But the model may also describe fairly well the very small size of bank reserves and net 
settlement payments relative to the large size of bank deposits and gross payments in modern economies in practice. For example, banks have no reserve requirements in the U.K., Canada, Australia, New Zealand and Sweden, and hold very low reserves. ${ }^{30}$ In 2004 , Canadian banks held $\$ 50$ million in central bank reserves, only $0.02 \%$ of the $\$ 270$ billion held of demand deposits, ${ }^{31}$ while New Zealand banks held $\$ 20$ million in central bank reserves, only $0.1 \%$ of the $\$ 20$ billion held of demand deposits. ${ }^{32}$ Even in the U.S., banks held $\$ 24$ billion in central bank reserves, ${ }^{33}$ only $0.5 \%$ of the $\$ 5.2$ trillion held of total bank deposits. ${ }^{34}$ From their reserves of $\$ 24$ billion, U.S. banks made on average $\$ 1.9$ trillion in gross payments per day through the Federal Reserve's clearinghouse system Fedwire, ${ }^{35}$ equivalent to a 79 times turnover ratio in reserves per day. Banks made an additional $\$ 1.2$ trillion in gross payments per day through the private clearinghouse CHIPS (in 1995), which after netting required only $\$ 7$ billion, or $0.6 \%$ of gross payments, in actual transfers of bank reserves per day to achieve settlement. ${ }^{36}$ In this context, the model assumptions of zero reserves and zero transfers of reserves for settlement of payments approximates the very small percentages of deposits and gross payments that these values take in practice.

\section{Conclusion}

The Federal Deposit Insurance Corporation (FDIC) has been widely credited for the drastic reduction in the occurrence of bank runs in the U.S. since it was established in 1933. However, FDIC only covers deposits up to a limited size, which is greatly exceeded by many large depositors. This paper can suggest an additional explanation for the decrease in bank runs. Nearly all of the theoretical bank run literature examines real demand deposits and describes historical bank runs based on currency withdrawals from the banking system. This paper adds to the Diamond-Dybvig model the features found in current practice of nominal deposits payable through a clearinghouse for monetary payments, interbank markets, and entrepreneurs taking loans and selling goods in a market outside of

\footnotetext{
${ }^{30}$ Woodford (2000).

${ }^{31}$ Amounts are Canadian dollars. Sources: Bank of Canada (2005) and International Monetary Fund (2005), respectively.

${ }^{32}$ Amounts are New Zealand dollars. Sources: Reserve Bank of New Zealand (2004) and International Monetary Fund (2005), respectively.

${ }^{33}$ Board of Governors of the Federal Reserve System (2005b).

${ }^{34}$ Board of Governors of the Federal Reserve System (2005a).

${ }^{35}$ Board of Governors of the Federal Reserve System (2006).

${ }^{36}$ Richards (1995).
} 
the banking system. Together, these features in a modern economy suggest that interbank lending and monetary market prices may be able to prevent pure liquidity runs.

First, flexible prices due to unbacked currency and a floating exchange rate in the U.S. in recent times imply that nominal contracts allow prices for goods to vary with the level of withdrawals, ensuring no purchase runs. Previous to FDIC, the value of money was tied to gold so deposits more resembled real contracts. Second, modern clearinghouses with instant electronic payments since the 1960s and 1970s imply that money is not depleted from the banking system when payments are made between banks, so interbank lending allows money to be efficiently distributed, ensuring no redeposit runs. In earlier times, currency withdrawals likely were the fastest, most confident method of withdrawing funds, given the risk of delays in transferring funds to another bank and the risk that a bank would not be able to borrow during the same day from other banks if depositors withdrew excessively.

This paper highlights how Diamond-Dybvig may continue to justify deposit insurance in developing countries with fixed exchange rates or bank deposits repayable in foreign currency. However, the Diamond-Dybvig justification for deposit insurance does not necessarily hold for developed countries. Demirguc-Kunt et al. (2005) show that deposit insurance is more likely to be adopted by generally more developed countries, where I argue it may be less needed, than in generally less developed economies, where it may be more needed, under the hypothesis that more developed countries adopt due to benefits to private interests. Given the evidence cited in the introduction that deposit insurance may increase bank failures due to moral hazard, but benefit private interests, this paper may lend support to the argument questioning whether deposit insurance may hurt more than help and may be adopted for rent-seeking reasons.

These resulting policy conclusions must be qualified because asset shocks are not examined in the current model. Large asset losses that threaten a bank's fundamental solvency would cause bank runs, so if this leads to inefficient liquidation then deposit insurance may be beneficial to provide for an orderly bank closure without liquidation. Examining this, along with asymmetric information in the interbank market, in a nominal contracts and interbank payments framework as presented here is needed to more fully understand nominal versus real effects and is left for further research. For example, Skeie (2004) shows that with nominal contracts, banks are hedged against aggregate real asset losses, but information breakdowns at the interbank level can lead to liquidity runs and conta- 
gion. Analysis on crises at the interbank level shows that deposit insurance cannot help, and instead a lender of last resort is necessary. Additional next steps for research include applying nominal contracts to study financial stability issues incorporating bank reserves, capital requirements and clearinghouse payment risks. 


\section{Appendix A: Robustness}

Price Indeterminacy I drop the zero profit condition that is imposed ex-post for the entrepreneur to examine the issue of price indeterminacy and the relationship between ex-ante and ex-post entrepreneur profit. I continue to assume the entrepreneur is a competitive price taker and that he maximizes revenue by choosing to sell goods in $t=1$ versus $t=2$. However, the assumption that the bank offers the entrepreneur debt contracts $K_{1}=1-\alpha$ and $K_{2}=\alpha r$ allows for the market equilibrium of zero entrepreneur profit as well as additional market equilibria that transfer allocations from consumers to the entrepreneur for positive entrepreneur profit. The price level at $t \in\{1,2\}$ and alloca-

tion of consumption is indeterminate. While the relative price level $\frac{P_{2}}{P_{1}}$ is determined, the indeterminacy of the absolute level of prices is a standard problem in general equilibrium theory. Here the indeterminacy effects real allocations between consumers and the entrepreneur's profits. Since the entrepreneur receives $P_{t} q_{t}^{S}=K_{t}$ at $t \in\{1,2\}$ for all $q_{t}>0$, he can always repay his loan, but $P_{t}$ and $q_{t}$ are not determined. Outcomes of lower consumption for consumers and positive profit for the entrepreneur are not inefficient because they are not Pareto-ranked. Rather they are simply transfers to the entrepreneur. The first order condition for the entrepreneur in (17) can be expressed as

$$
\begin{array}{ll}
q_{2} \in\left[(1-\lambda) D_{1},(1-\lambda) D_{2}\right] & \text { if } q_{1}=\lambda D_{1} \\
q_{2}=\left(\frac{1-\lambda}{\lambda}\right) q_{1} & \text { if } q_{1}<\lambda D_{1}
\end{array}
$$

If $q_{1}=\lambda D_{1}, P_{1}=1$. Any $P_{2} \in\left(1, D_{1,2}\right]$ corresponding to $q_{2} \in\left[(1-\lambda) D_{1},(1-\lambda) D_{2}\right)$ in (38) implies the entrepreneur profits at the late consumers' expense. However, late consumers do not run according to (20) and the entrepreneur's first order condition (18), which holds since discounted $P_{2}$ is still lower than $P_{1}$. If $q_{1}<\lambda D_{1}, P_{1}$ and $P_{2}$ are greater than one, implying the entrepreneur profits at the early and late consumers' expense. The entrepreneur's first order condition (18) is binding and there is no run according to (20).

The possibility for positive entrepreneur profit and price indeterminacy may be resolved by the bank offering different loan repayment contracts. If there is any positive probability at $t=0$ of an equilibrium with $P_{2}>1$ in which the entrepreneur profits under the original $K_{1}$ and $K_{2}$ contracts, the entrepreneur has an ex-ante expected positive profit. The bank can offer debt contracts of $K_{1}=1-\alpha$ and $K_{2}=\alpha r+\varepsilon$, where $\varepsilon>0 . K_{2}>\alpha r$ implies 
the entrepreneur always defaults at $t=2$, which requires that $q_{2}^{S}=\widehat{q}_{2}^{S}$, so $P_{t}=1$ and the consumers' allocation is $\left(c_{1}^{*}, c_{2}^{*}\right)$ as the unique equilibrium. Even though the entrepreneur always defaults in equilibrium, due to limited liability the entrepreneur makes zero profit. However, the zero profit condition is imposed her ex-ante instead of ex-post.

Stable Market Equilibrium Price determinacy may also be resolved without requiring the entrepreneur to default in equilibrium using a stable market equilibrium concept. The zero entrepreneur profit allocation is the unique outcome and prices are uniquely determined without a zero profit condition imposed ex-post.

A stable market equilibrium is defined as the limiting case of an $\epsilon$-equilibrium in which $\epsilon \in(0,1-\lambda)$ late consumers do not withdraw in any period. An $\epsilon$-model is equivalent to the multiple-bank model with the following modifications. A fraction $\lambda$ consumers are early, $1-\lambda-\epsilon$ consumers are late, and $\epsilon>0$ consumers die unexpectedly at the start of $t=1$ before they have a chance to withdraw. Thus, $\lambda^{w} \leq 1-\epsilon$.

First, I consider the single-bank model. The variables $q_{t}^{S}(\epsilon), q_{t}(\epsilon)$ and $P_{t}(\epsilon)$ are substituted in the model for $q_{t}^{S}, q_{t}$ and $P_{t}$. Equation (9) is replaced by

$$
P_{2}(\epsilon) q_{2}(\epsilon)=\left(1-\lambda^{p}-\epsilon\right) D_{2}
$$

An $\epsilon$-equilibrium of the $\epsilon$-model is defined as a competitive market equilibrium $\left(P_{t}(\epsilon), q_{t}(\epsilon)\right)$ and a $\lambda^{p}$ Nash equilibrium of the late consumers' problem.

I define a competitive market equilibrium $\left(P_{t}, q_{t}\right)$ for $t \in\{1,2\}$ as a stable market equilibrium if $q_{t}=\lim _{\epsilon \rightarrow 0} q_{t}(\epsilon)$. For $\epsilon>0, q_{2}^{S}(\epsilon) P_{2}(\epsilon)<K_{2}$, so there is not enough money paid for goods for the entrepreneur to repay $K_{2}$. The entrepreneur defaults on repaying $K_{2}$ by an amount $\epsilon D_{2}$. Hence, the entrepreneur must sell all goods available $q_{2}^{S}(\epsilon)=\widehat{q}_{2}^{S}$ at $t=2$. The entrepreneur's first order condition (17) is unchanged in the $\epsilon$-equilibrium. It is shown in the proof below that this implies he sells all goods $q_{1}^{S}(\epsilon)=\widehat{q}_{1}^{S}=1-\alpha+\gamma s$ at $t=1$ as well. The late consumer's condition for early purchases (20) contradicts (18), so late consumers withdraw at $t=2$. In the $\epsilon$-equilibrium, for all $\epsilon$, there is no run, and $\left(P_{t}(\epsilon), q_{t}(\epsilon)\right)$ is determined as $P_{1}(\epsilon)=\frac{\lambda D_{1}}{\widehat{q}_{1}^{S}}, P_{2}(\epsilon)=\frac{(1-\lambda-\epsilon) D_{2}}{\widehat{q}_{2}^{S}}$ and $q_{t}(\epsilon)=\widehat{q}_{t}^{S}$. Hence, in the stable market equilibrium, $\left(P_{t}, q_{t}\right)$ is determined as $P_{1}=\frac{\lambda D_{1}}{\widehat{q}_{1}^{S}}, P_{2}=\frac{(1-\lambda) D_{2}}{\widehat{q}_{2}^{S}}$ and $q_{t}=\widehat{q}_{t}^{S}$. By the entrepreneur maximizing his revenues, the market price mechanism provides optimal goods at $t \in\{1,2\}$. The entrepreneur does not liquidate any invested 
goods at $t=1$ and does not store any goods from $t=1$ to $t=2$.

Second, I consider the multiple-bank model. The stable market equilibrium is defined as in the single-bank model, with the exception that (8) and (9) are replaced by

$$
\begin{aligned}
P_{1}(\epsilon) q_{1}(\epsilon) & =\lambda^{p} \delta_{1} D_{1} \\
P_{2}(\epsilon) q_{2}(\epsilon) & =\left(1-\lambda^{w}-\epsilon\right) \delta_{2} D_{2}+\left(\lambda^{w}-\lambda^{p}\right) \delta_{1} D_{1} \delta_{2}^{B} D_{2}^{B} .
\end{aligned}
$$

For any $\epsilon$-equilibrium, the entrepreneur defaults at $t=2$. He receives $\left(1-\lambda^{p}-\epsilon\right) D_{2}+\left(\lambda^{p}-\right.$ त) $D_{1} D_{2}^{B}$ from purchasers at $t=2$ and from his deposits at bank B. Since $D_{2}^{B}=\frac{D_{2}}{D_{1}}$, the entrepreneur's revenues at $t=2$ are less than $K_{2}$ by the amount $\epsilon D_{2}$. The entrepreneur must sell $q_{2}^{S}(\epsilon)=\widehat{q}_{2}^{S}$ at $t=2$ due to the default. The entrepreneur's first order condition (17) is unchanged and implies that $q_{1}^{S}(\epsilon)=\widehat{q}_{1}^{S}$.

Bank A does not default. Since it owes only $\left(1-\lambda^{w}-\epsilon\right) D_{2}$ on deposits at $t=2$, it owes $\epsilon D_{2}$ less on deposits at $t=2$ than otherwise, equal to the amount by which the entrepreneur defaults. Bank A receives from the entrepreneur at $t=2$ the amount it owes on deposits plus $F D_{2}^{B}$ due to bank B. Thus, bank B lends fully to bank A at a rate of $\frac{D_{2}}{D_{1}}$. The late consumers' optimization in the multiple-bank $\epsilon$-model collapses to that of the single-bank $\epsilon$-model, so there is no run. Since $q_{t}^{S}(\epsilon)=\widehat{q}_{t}^{S}$ is determined, the stable market equilibrium is determined as $\left(P_{t}, \widehat{q}_{t}^{S}\right)$.

Proposition 6. The allocation in the unique stable market equilibrium of the single-bank model and the multiple-bank model is the consumers' ex-ante optimal consumption $\left(c_{1}^{*}, c_{2}^{*}\right)$, and zero entrepreneur profits.

Proof. See Appendix Proofs. 


\section{Appendix B: Proofs}

Proof of Proposition 1: The market clearing price of invested goods in terms of stored goods at $t=1$ is $p_{i n v}=\frac{(1-\lambda)\left(1-\alpha^{*}\right)}{\lambda \alpha^{*}}$. Consumption is given by

$$
\begin{aligned}
c_{1} & =1-\alpha^{*}+\frac{(1-\lambda)\left(1-\alpha^{*}\right)}{\lambda}=\frac{1-\alpha^{*}}{\lambda}=c_{1}^{*} \\
c_{2} & =\alpha^{*} r+\frac{\lambda \alpha^{*} r}{1-\lambda}=\frac{\alpha^{*} r}{1-\lambda}=c_{2}^{*} .
\end{aligned}
$$

The trade is incentive compatible for late consumers since the value of invested goods received from trading is greater than the value of current goods paid,

$$
\frac{\left(1-\alpha^{*}\right) r}{p_{i n v}}=\lambda c_{2}^{*}>\lambda c_{1}^{*}=\left(1-\alpha^{*}\right)
$$

The trade is incentive compatible for early consumers if the value of liquid goods received from trading is greater than the value of liquidating invested goods,

$$
p_{\text {inv }} \alpha^{*}=\frac{c_{1}^{*} \alpha^{*} r}{c_{2}^{*}}>s \alpha^{*}
$$

which holds since the coefficient of relative risk aversion greater than one implies $\frac{c_{2}^{*}}{c_{1}^{*}}<r$. Q.E.D.

Proof of Lemma 1: The nonnegative Lagrange multipliers associated with the constraints (16b) and (16c) are $\theta_{1}$ and $\theta_{2}$. The necessary Kuhn-Tucker conditions are:

$$
\begin{aligned}
D_{1,2} \frac{P_{1}}{P_{2}} & =1+\theta_{1} \\
r-s+\theta_{2} & \geq \theta_{1} s,
\end{aligned}
$$

and combining (40) and (41) gives

$$
s D_{1,2} \frac{P_{1}}{P_{2}} \leq r\left(1+\theta_{2}\right)
$$

with (41) and (42) binding if $\gamma>0$.

First I show that the definition of $P_{2}^{1} \in(0, \infty)$ is consistent with the entrepreneur's choice of $q_{2}^{S}$. Consider $\lambda^{p}=1$. Suppose the entrepreneur sells goods at $t=2, q_{2}^{S}>0$. This implies $P_{2}=0$, and also that either $\theta_{1}$ or $\theta_{2}$ equals zero by complementary slackness, 
which is a contradiction to either (40) or (42), respectively, since $P_{1}>0$. Hence, $q_{2}^{S}=0$ and since $\left(1-\lambda^{p}\right)=0, P_{2}\left(\lambda^{p}=1\right)$ is undefined by $(9)$. For any $P_{2}^{1} \in(0, \infty)$, there exists $q_{1} \in[0,1-\alpha+\gamma s]$ such that $\theta_{1}=\frac{D_{2}}{P_{2} q_{1}}-1 \geq 0$ and $\theta_{2}=\frac{s D_{2}}{r P_{2} q_{1}}-1 \geq 0$, implying (40) and (42) hold. For illustration, if $P_{2}$ is low, then $\gamma>0$ and $\theta_{1}$ and $\theta_{2}$ are high. If $P_{2}$ is high, then $q_{1}<1-\alpha, P_{1}$ is high, and $\theta_{1}=\theta_{2}=0$.

I have shown in the text that $K_{1}$ is always repaid for $q_{1}^{S}>0$. Suppose $q_{1}^{S}=0$. $\left.q_{1}^{S} P_{1}\right|_{q_{1}^{S}=0}=0$ by definition, so the entrepreneur defaults. This require $q_{1}^{S}=\widehat{q}_{1}^{S}>0$, a contradiction. Thus $q_{1}^{S}>0$. To show $K_{2}$ is repaid, consider the case of $\lambda^{p}=1$. This implies $q_{1}^{S} P_{1}=D_{1}$, which after the entrepreneur repays $K_{1}$ at $t=1$ leaves $D_{1}-K_{1}$ for deposit at rate $D_{1,2}$. The deposit value is $\left(D_{1}-K_{1}\right) D_{1,2}=K_{2}$ to repay $K_{2}$ at $t=2$.

Next consider the case of $\lambda^{p}<1$. Suppose $q_{2}=0$. This implies $P_{2}=\infty$, so by (40), $1+\theta_{1}=0$, a contradiction to $\theta_{1} \geq 0$. Thus, $q_{2}>0$ and $q_{2} P_{2}=\left(1-\lambda^{p}\right) D_{2}$. The entrepreneur has at $t=2$ available to repay $\left(q_{1} P_{1}-K_{1}\right) D_{1,2}+q_{2} P_{2}=\left(\lambda^{p}-\lambda\right) D_{2}+(1-\lambda) D_{2}=K_{2}$ so never defaults. Q.E.D.

Proof of Proposition 2: A late consumer withdraws at $t=1$ to purchase goods if and only if (20) hold. Since (18) holds in any market equilibrium, withdrawing at $t=1$ is a strictly dominated strategy. Withdrawing at $t=2$ is a dominant strategy for each late consumer. Thus, $\lambda^{p}=\lambda$ and no purchase runs is the unique Nash equilibrium and is an equilibrium in dominant strategies. Q.E.D.

Proof of Proposition 3: First, I prove (19). Suppose $\gamma>0$ and $q_{1}^{S}<1-\alpha+\gamma s$. This implies $\theta_{1}=0$ by complementary slackness, and (41) binding implies $r=s-\theta_{2}<s$, a contradiction to $r>s$. Thus, $\gamma>0$ implies $q_{1}^{S}=1-\alpha+\gamma s$. Next, suppose $\gamma=\alpha$. Substituting $P_{2}=\infty$ in (40) implies $1+\theta_{1}=0$, a contradiction to $\theta_{1} \geq 0$. Thus, $\gamma<\alpha$, $\theta_{2}=0$ due to complementary slackness and $\gamma>0$ implies $s P_{1}=r \frac{P_{2}}{D_{1,2}}$.

Next, I show that $q_{1}=\widehat{q}_{1}^{S}$. Suppose not: $q_{1}^{S}<\widehat{q}_{1}^{S}$. This implies $\theta_{1}=0$, so after substituting for prices in (17), recognizing $\widehat{q}_{2}^{S} \geq(\alpha-\gamma) r$ and rearranging, $q_{1} \geq \frac{\lambda^{p}(\alpha-\gamma) r}{1-\lambda^{p}}$. Suppose $\gamma=0$. This implies $q_{1} \geq \lambda D_{2}>\lambda D_{1}$, which implies $\gamma>0$, a contradiction. Thus, $\gamma>0$ implies $s P_{1} D_{1,2}=r P_{2}$, but by (17), $P_{1} D_{1,2}=P_{2}$, implying $s=r$, a contradiction. Thus $q_{1}^{S}=\widehat{q}_{1}^{S}$.

Finally, suppose $\gamma>0$. By substituting into (19) for prices and $q_{t}=\widehat{q}_{t}^{S}$ for $t \in$ $\{1,2\}: \frac{s \lambda D_{1}}{\lambda D_{1}+\gamma s}=\frac{r(1-\lambda) D_{2}}{D_{1,2}(\alpha-\gamma) r}$. The LHS is less than $s$, while the RHS is greater than one, a contradiction to $s<1$. Thus, $q_{1}=1-\alpha, q_{2}=\alpha r, P_{t}=1$ and $\left(c_{1}, c_{2}\right)=\left(c_{1}^{*}, c_{2}^{*}\right)$. Q.E.D. 
Proof of Lemma 2: First I show $\phi=1$ in (28) and (31) binds. Since $\phi F \leq I_{2}^{B}=$ $\delta_{1} \lambda^{w} D_{1}-\kappa_{1} K_{1}-\kappa_{1,2} K_{2}$, and $(22)$ can be written as $\phi F \geq \lambda^{w} \delta_{1} D_{1}-\kappa_{1} K_{1}-\kappa_{1,2} K_{2}$, (22) is binding. If $\kappa_{1,2}>0$, then $\phi=1$ from the definition of $\kappa_{1,2}$. If $\kappa_{1,2}=0$, then (22) is $\phi F+\min \left\{\lambda D_{1}, \lambda^{p} \delta_{1} D_{1}\right\}=\lambda^{w} \delta_{1} D_{1}$. Since $F \geq 0$ and $\lambda^{p} \leq \lambda^{w}, \delta_{1}(\phi)$ is always weakly increasing in $\phi$. Because $\delta_{2}<1$ implies $\delta_{2}^{F}=0, \delta_{2}$ does not depend on $\phi$ in (23). Thus, $\phi=1$ maximizes $\delta_{1}(\phi)+\delta_{2}(\phi)$ for all $\lambda^{p}$ and $\lambda^{w}$.

Moreover, (23) binds, implying $F=I_{2}^{B}$ and (31) binds. Equation (22) can be rewritten as $\lambda^{w} \delta_{1} D_{1} \geq \lambda^{w} \delta_{1} D_{1}$, so bank A can choose $\delta_{1}=1$. Substituting this into the definition of $\kappa_{1}, \kappa_{1}=1$. Since $(22)$ holds with $\kappa_{1,2}=0$, this is the solution for $\kappa_{1,2}$.

Substituting these solutions into (23) and rearranging,

$$
\delta_{2}^{F} D_{2}^{F} \leq \frac{\left[\kappa_{2}(1-\lambda)-\delta_{2}\left(1-\lambda^{w}\right)\right] D_{2}}{\left(\lambda^{w}-\lambda\right) D_{1}}
$$

I claim bank A chooses $\delta_{2}=1$, which satisfies (28); bank B chooses $D_{2}^{B}=D_{2}^{F}=\frac{D_{2}}{D_{1}}$ and $\delta_{2}^{B}=1$, which satisfies (32) and (33); and show (23) and (34) are satisfied and $\delta_{2}^{F}=1$. Substituting $\delta_{2}=1$ into (43), $\delta_{2}^{F} D_{2}^{F} \leq \frac{D_{2}}{D_{1}}$ since

$$
\kappa_{2} \leq 1
$$

satisfying (34). Applying these results and (32) to the definition of $\kappa_{2}$,

$$
\kappa_{2}=\frac{\min \left\{K_{2},(1-\lambda) D_{2}\right\}}{K_{2}}=1
$$

Hence, (43) and so (23) hold with equality and $\delta_{2}^{F}=1$.

Proof of Proposition 4: After substituting results from Lemma 2, the proof follows that of Proposition 2 and Proposition 3. Q.E.D.

Proof of Proposition 5: Substituting $P_{1}\left(\bar{\lambda}^{p}>\lambda\right)=\frac{\Delta \bar{\lambda}^{p} D_{1}}{\Delta \bar{q}_{1}^{S}}$ in (19) and simplifying gives $\Delta \bar{\lambda}^{p}=\Delta \bar{\gamma}\left(\frac{1-\lambda^{p}}{\alpha-\gamma}\right)$. Integrating, $\int_{\lambda}^{\lambda^{p}} d \bar{\lambda}^{p}=\left(\frac{1-\lambda^{p}}{\alpha-\gamma}\right) \int_{0}^{\gamma} d \bar{\gamma}$. Solving and rearranging gives $\gamma=\frac{\alpha\left(\lambda^{p}-\lambda\right)}{1-\lambda}$, which substituting into the definition of $P_{2}$ gives $P_{2}=1$. Q.E.D.

Proof of Proposition 6: First, I prove (39). If $q_{1}<\lambda D_{1}, \gamma=0$ and $\theta_{1}=0$ by complementary slackness. By (19), $q_{2}=\frac{1-\lambda}{\lambda} q_{1}$. Next I prove (38). If $q_{1}=\lambda D_{1}$, (19) shows $q_{2} \geq(1-\lambda) D_{1}$ since $\theta_{1} \geq 0$. The feasibility condition $q_{2} \leq \widehat{q}_{2}^{S}$ implies $q_{2} \in$ $\left[(1-\lambda) D_{1},(1-\lambda) D_{2}\right]$. 
Now, consider the $\epsilon$-model in the single bank model. Substituting in $q_{t}(\epsilon)$ and $P_{t}(\epsilon)$, the late consumers' optimization problem and the entrepreneur's maximization problem are identical. The entrepreneur does not default at $t=1$ and repays $(1-\lambda-\epsilon) D_{2}$ following the argument from the proof for Lemma 1. The amount of default by the entrepreneur of $\epsilon D_{2}$ is the amount the bank does not repay to late consumers who die, thus the bank does not default. Since the entrepreneur default at $t=1$ does not change his maximization problem, the first-order conditions given by (17), (18) and (19) continue to hold.

To show that $q_{1}=\widehat{q}_{1}^{S}$, suppose $q_{1}^{S}<\widehat{q}_{1}^{S}$. This implies $\theta_{1}=0$, so after substituting for prices in (17), recognizing $\widehat{q}_{2}^{S} \geq(\alpha-\gamma) r$ and rearranging, $q_{1} \geq \frac{\lambda^{p}(\alpha-\gamma) r}{1-\lambda^{p}-\epsilon}$. Suppose $\gamma=0$. This implies $q_{1} \geq \lambda D_{2}>\lambda D_{1}$, which implies $\gamma>0$, a contradiction. Thus, $\gamma>0$ implies $s P_{1} D_{1,2}=r P_{2}$, but by (17), $P_{1} D_{1,2}=P_{2}$, implying $s=r$, a contradiction. Thus $q_{1}^{S}=\widehat{q}_{1}^{S}$.

Next, I show that prices and outcomes are determined. Substituting the definitions of $P_{t}(\epsilon)$ and $\widehat{q}_{t}^{S}(\epsilon)$ into (19) and rearranging, $\gamma=\frac{s \lambda^{p} \alpha-(1-\alpha)\left(1-\lambda^{p}-\epsilon\right)}{s \lambda^{p}+s\left(1-\lambda^{p}-\epsilon\right)}$ when it exists, otherwise $\gamma=0$. Either way, $\gamma, \widehat{q}_{t}^{S}(\epsilon), P_{t}(\epsilon)$ and $c_{t}(\epsilon)=\frac{D_{t}}{P_{t}}$ are determined.

Lastly, consider the multiple-bank model. To examine the $\epsilon$-model in the multiplebank model, substitute for $P_{t}(\epsilon)$ and $q_{t}(\epsilon)$ as defined in the single-bank model, substitute for

$$
\kappa_{2}(\epsilon) \equiv \frac{\min \left\{\left(1-\kappa_{1,2}\right) K_{2},\left(1-\lambda^{w}-\epsilon\right) \delta_{2} D_{2}+\left[\left(\delta_{1} \lambda^{w}-\kappa_{1} \lambda\right) D_{1}-\kappa_{1,2} K_{2}\right] \delta_{2}^{B} D_{2}^{B}\right.}{\left(1-\kappa_{1,2}\right) K_{2}}
$$

and replace $(23)$ with

$$
t=2: \quad\left(1-\lambda^{w}-\epsilon\right) \delta_{2} D_{2}+\phi F \delta_{2}^{F} D_{2}^{F} \leq \kappa_{2}\left(1-\kappa_{1,2}\right) K_{2}
$$

The argument and proof for Lemma 2 holds with the exception that (43) is replaced with

$$
\delta_{2}^{F} D_{2}^{F} \leq \frac{\left[\kappa_{2}(1-\lambda)-\delta_{2}\left(1-\lambda^{w}-\epsilon\right)\right] D_{2}}{\left(\lambda^{w}-\lambda\right) D_{1}}
$$

(44) is replaced with $\kappa_{2} \leq \frac{1-\lambda-\epsilon}{1-\lambda}$ and (45) is replaced with $\kappa_{2}=\frac{\min \left\{K_{2},(1-\lambda-\epsilon) D_{2}\right\}}{K_{2}}=\frac{1-\lambda-\epsilon}{1-\lambda}$. Thus, there is full lending by bank B, $\kappa_{1,2}=0$ and there are no defaults with the exception that $\kappa_{2}<1$. The remaining argument and proof for the entrepreneur's and late consumers' optimizations in the $\epsilon$-model of the multiple-bank model are identical to that of the $\epsilon$-model of the single bank model. Q.E.D. 


\section{References}

[1] Aghion, Philippe, Mathias Dewatripont and Patrick Bolton (2000), "Contagious Bank Failures in a Free Banking System," European Economic Review, 44, 713-718.

[2] Allen, Franklin and Douglas Gale (1998), "Optimal Financial Crises," Journal of Finance, 53(4), 1245-1283.

[3] Allen, Franklin and Douglas Gale (2000a), "Financial Contagion," Journal of Political Economy, 108(1), 1-33.

[4] Allen, Franklin and Douglas Gale (2000b), "Optimal Currency Crises," CarnegieRochester Series on Public Policy, 53, 177-230.

[5] Allen, Franklin and Douglas Gale (2004), "Financial Intermediaries and Markets," Econometrica, 72(4), 1023-1061.

[6] Bank of Canada (2005), "A Primer on the Implementation of Monetary Policy in the LVTS Environment," [Found February 21, 2006 at http://www.bankofcanada.ca/en/lvts/primer_2005e.html].

[7] Bhattacharya, Sudipto and Douglas Gale (1987), "Preference Shocks, Liquidity and Central Bank Policy," in William Barnett and Kenneth Singleton, eds: New Approaches to Monetary Economics (Cambridge University Press, New York, N.Y.).

[8] Bhattacharya, Sudipto and Paolo Fulghieri (1994), "Uncertain Liquidity and Interbank Contracting," Economics Letters, 44, 287-294.

[9] Board of Governors of the Federal Reserve System (2005a), "Report on the Condition of the U.S. Banking Industry: Second Quarter, 2005," Federal Reserve Bulletin, Autumn 2005.

[10] Board of Governors of the Federal Reserve System (2005b), 91st Annual Report of the Board of Governors of the Federal Reserve System: 2004.

[11] Board of Governors of the Federal Reserve System (2006), Fedwire Funds Service, Last update: March 8, 2005, [Found on February 21, 2006 at http://www.federalreserve.gov/paymentsystems/fedwire/fedwirefundstrfann.htm]. 
[12] Boyd, John H. Chun Chang and Bruce D. Smith (2004a), "Deposit Insurance and Bank Regulation in a Monetary Economy: A General Equilibrium Exposition," Economic Theory, 24, 741-767.

[13] Boyd, John H., Gianni De Nicolo and Bruce D. Smith (2004b), "Crises in Competitive versus Monopolistic Banking Systems," Journal of Money, Credit, and Banking, 36(3), 487-506.

[14] Bryant, John (1980), "A Model of Reserves, Banks Runs, and Deposit Insurance," Journal of Banking and Finance, 4, 335-344.

[15] Calomiris, Charles W. and Charles M. Kahn (1991), "The Role of Demandable Debt in Structuring Optimal Banking Arrangements," American Economic Review, 81(3), 497-513.

[16] Champ, Bruce, Bruce D. Smith and Stephen D. Williamson (1996), "Currency Elasticity and Banking Panics: Theory and Evidence," Canadian Journal of Economics, $29(4), 828-864$.

[17] Chang, Roberto and Andres Velasco (2000), "Financial Fragility and the Exchange Rate Regime," Journal of Economic Theory, 92, 1-34.

[18] Chari, V. V. and Ravi Jagannathan (1988), "Banking Panics, Information, and Rational Expectations Equilibrium," Journal of Finance, 43 (3), 749-61.

[19] Demirguc-Kunt, Asli and Enrica Detragiache (1997), "The Determinants of Banking Crises: Evidence from Developing and Developed Countries," IMF Working Paper, $\mathrm{WP} / 97 / 106$.

[20] Demirguc-Kunt, Asli and Enrica Detragiache (2002), "Does Deposit Insurance Increase Banking System Stability? An Empirical Investigation," Journal of Monetary Economics, 49, 1373-1406.

[21] Demirguc-Kunt, Asli, Enrica Detragiache and Poonam Gupta (2004), "Inside the Crisis: An Empricial Analysis of Banking Systems in Distress," working paper.

[22] Demirguc-Kunt, Asli, Edward J. Kane and Luc Laeven (2005), "Determinants of Deposit Insurance Adoption and Design," working paper. 
[23] Diamond, Douglas W. and Philip H. Dybvig (1983), "Bank Runs, Deposit Insurance, and Liquidity," Journal of Political Economy, 91(3), 401-419.

[24] Diamond, Douglas W. and Raghuram G. Rajan (2005), "Liquidity Shortages and Banking Crises," Journal of Finance, 60(2), 615-47.

[25] Diamond, Douglas W. and Raghuram G. Rajan (2006), "Money in a Theory of Banking," American Economic Review, forthcoming.

[26] Flannery, Mark J. (1996), "Financial Crises, Payment System Problems, and Discount Window Lending," Journal of Money, Credit, and Banking, 28(4), 804-824.

[27] Freeman, Scott (1996), "The Payments System, Liquidity, and Rediscounting," American Economic Review, 86(5), 1126-1138.

[28] Freixas, Xavier and Cornelia Holthausen (2005), "Interbank Market Integration under Asymmetric Information," Review of Financial Studies, 18(2), 459-90.

[29] Freixas, Xavier, Bruno M. Parigi, and Jean-Charles Rochet (2000), "Systemic Risk, Interbank Relations, and Liquidity Provision by the Central Bank," Journal of Money, Credit, and Banking, 32(3), 611-638.

[30] Freixas, Xavier, Bruno M. Parigi, and Jean-Charles Rochet (2004), "The Lender of Last Resort: A Twenty-First Century Approach," Journal of the European Economic Association, 2(6), 1085-1115.

[31] Friedman, Milton and Anna J. Schwartz (1963), A Monetary History of the United States, 1867-1960, (Princeton University Press, Princeton).

[32] Furfine, Craig H. (1999), "The Microstructure of the Federal Funds Market," Financial Markets, Institutions 63 Instruments, 8(5), 24-44.

[33] Gale, Douglas and Xavier Vives (2002), "Dollarization, Bailouts, and the Stability of the Banking System," Quarterly Journal of Economics, 117(2), 467-502.

[34] Gorton, Gary (1988), "Banking Panics and Business Cycles," Oxford Economic Papers, 40, 751-781.

[35] Green, Edward J. (1999a), "Money and Debt in the Structure of Payments," Federal Reserve Bank of Minneapolis Quarterly Review, 23(2), 13-29. 
[36] Green, Edward J. (1999b), "We Need to Think Straight about Electronic Payments," Journal of Money, Credit \&3 Banking, 31(3), 668-670.

[37] Henckel, Timo, Alain Ize, and Arto Kovanen (1999), "Central Banking Without Central Bank Money," IMF Working Paper, WP/99/92.

[38] International Monetary Fund (2005), International Financial Statistics, 58(12).

[39] Jacklin, Charles J. (1987), "Demand Deposits, Trading Restrictions, and Risk Sharing," in Edward C. Prescott and Neil Wallace, eds: Contractual Arrangements for Intertemporal Trade (University of Minnesota Press, Minneapolis).

[40] Kane, Edward J. (1989), The SESL insurance mess: How did it happen? (Urban Institute Press, Washington, D.C.).

[41] Kitson, Arthur (1895), A Scientific Solution of the Money Question (Arena, Boston).

[42] Kim, D. and A. Santomero (1988), "Risk in Banking and Capital Regulation," Journal of Finance, 43(5), 1219-1233.

[43] Koeppl, Thorsten, Cyril Monnet and Ted Temzelides (2006), "Transactions, Settlement, and Mechanism Design," working paper.

[44] Kroszner, Randall S. (1998), "The Political Economy of Banking and Financial Regulatory Reform in Emerging Markets," Research in Financial Services, 10, 33-51.

[45] Kroszner, Randall S. and P. Strahan (2001), "Obstacles to Optimal Policy: The Interplay of Politics and Economics in Shaping Bank Supervision and Regulation Reforms," in F.S. Mishkin, ed: Prudential Supervision: What Works and What Doesn't (University of Chicago Press, Chicago), 233-273.

[46] Laeven, Luc (2004), "The Political Economy of Deposit Insurance," Journal of Financial Services Research, 26(3), 201-224.

[47] Martin, Antoine (2005) "Reconciling Bagehot with the Fed's Response to September 11,” Federal Reserve Bank of New York Staff Reports, No. 217.

[48] Martin, Antoine (2006) "Liquidity Provision vs. Deposit Insurance: Preventing Bank Panics without Moral Hazard," Economic Theory, 28(1), 197-211. 
[49] McAndrews, James J. and William Roberds (1995), "Banks, Payments, and Coordination," Journal of Financial Intermediation, 4, 305-327.

[50] McAndrews, James J. and William Roberds (1999), "Payment Intermediation and the Origins of Banking," Federal Reserve Bank of New York Staff Reports, No. 85.

[51] Nagarajan, S. and C.W. Sealey (1995), "Forebearnace, Deposit Insurance Pricing, and Incentive Compatible Bank Regulation," Journal of Banking and Finance, 19(6), 1109-1130.

[52] Peck, James and Karl Shell (2003), "Bank Portfolio Restrictions and Equilibrium Bank Runs," working paper.

[53] Penati, A. and A. Protopapadakis (1988), "The Effect of Implicit Deposit Insurance on Banks' Portfolio Choices with an Application to International 'Overexposure'," Journal of Monetray Economics, 21(1), 107-126.

[54] Postlewaite, Andrew, Xavier Vives (1987), "Bank Runs as an Equilibrium Phenomenon," Journal of Political Economy, 95(3), 485-491.

[55] Repullo, Rafael (2000), "Who Should Act as Lender of Last Resort? An Incomplete Contracts Model," Journal of Money, Credit, and Banking, 32(3), 580-605.

[56] Reserve Bank of New Zealand (2004), "Liquidity Management in the New Zealand Banking System," Bulletin, 67(4).

[57] Richards, Heidi Willmann (1995), "Daylight Overdraft Fees and the Federal Reserve's Psystem Risk Policy," Federal Reserve Bulletin, December 2005, 1065-1077.

[58] Rochet, Jean-Charles and Jean Tirole (1996), "Interbank Lending and Systemic Risk," Journal of Money, Credit, and Banking, 28(4), 733-762.

[59] Rochet, Jean-Charles and Xavier Vives (2004), "Coordination Failures and the Lender of Last Resort: Was Bagehot Right After All?," Journal of the European Economic Association, 2(6), 1116-1147.

[60] Skeie, David R. (2004), "Money and Modern Bank Runs," working paper, Federal Reserve Bank of New York. 
[61] Smith, Bruce D. (2003), "Taking Intermediation Seriously," Journal of Money, Credit, and Banking, 35(6), 1319-1357.

[62] von Mises, Ludwig (1912/1971), Theorie des Geldes und der Unlaufsmittle (Duncker \& Humblot, Munich). English ed.: The Theory of Money and Credity (Found. Econ. Education, Irving-on-Hudson, N.Y.).

[63] Wallace, Neil (1988), "Another Attempt to Explain an Illiquid Banking System: The Diamond and Dybvig Model with Sequential Service Taken Seriously," Federal Reserve Bank of Minneapolis Quarterly Review, 12(4), 3-16.

[64] Wicksell, Knut (1935), Lectures on Political Economy, Volume Two: Money; Edited with an Introduction by Lionel Robbins, (Routledge and Sons, Ltd., London).

[65] Woodford, Michael (2000), "Monetary Policy in a World Without Money," International Finance, 3(2) 229-260. 